\title{
Influence of edaphic conditions and nitrogen fertilizers on cadmium and zinc phytoextraction efficiency of Noccaea caerulescens
}

\author{
Arnaud Jacobs ${ }^{\mathrm{a}, *}$, Nausicaa Noret ${ }^{\mathrm{a}}$, Alexandre Van Baekel ${ }^{\mathrm{a}}$, Amandine Liénard ${ }^{\mathrm{b}}$, \\ Gilles Colinet ${ }^{\mathrm{b}}$, Thomas Drouet $^{\mathrm{a}}$ \\ a Laboratoire d'Écologie Végétale et Biogéochimie, CP 244, Faculté des Sciences, Université libre de Bruxelles, 50 av. F. D. Roosevelt, 1050 Brussels, Belgium \\ b BIOSE Department, Soil-Water-Plant Exchanges, University of Liège, Gembloux Agro-Bio Tech, 2 Passage des Déportés, 5030 Gembloux, Belgium
}

\section{H I G H L I G H T S}

- Noccaea caerulescens was grown on 24 soils characterized by 22 soil variables.

- Growth depended more on soil physical (organic matter) than on chemical variables.

- Low soil copper content $\left(<50 \mathrm{mg} \mathrm{kg}^{-1}\right)$ and sand negatively affected shoot biomass.

- Nitrogen fertilization did not improve zinc or cadmium uptake.

- Shoot cadmium and zinc concentrations relied on soil exchangeable concentrations.

\section{A R T I C L E I N F O}

\section{Article history:}

Received 11 September 2018

Received in revised form 4 February 2019

Accepted 4 February 2019

Available online 07 February 2019

Editor: Charlotte Poschenrieder

\section{Keywords:}

Nitrate

Fertilization

Hyperaccumulation

Phytoremediation

Lead

Copper

\section{G R A P H I C A L A B S T R A C T}

METAL UPTAKE BY NOCCAEA CAERULESCENS DEPENDS ON:
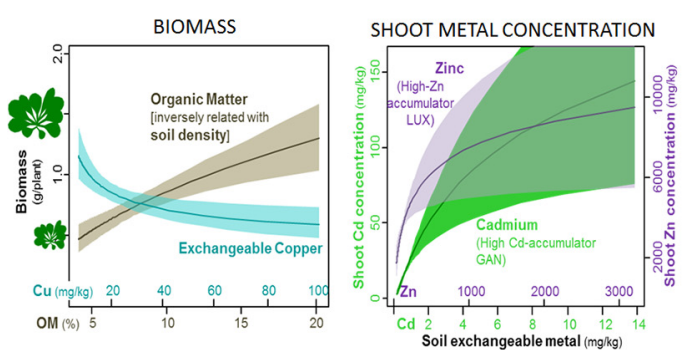

\section{EFFECT OF NITROGEN FERTILIZATION}

BIOMASS لL SHOOT METAL

INCREASE CONCENTRATION DECREASE

NO EFFECT ON METAL UPTAKE High-Cd $\rightleftharpoons$ High-Zn
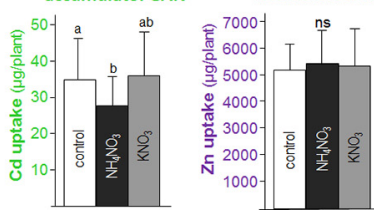
accumulator GAN accumulator LUX

\section{A B S T R A C T}

The success of cadmium phytoextraction operations with Noccaea caerulescens varies by a factor of 70 between sites of trials. However, soil factors driving the efficiency of cadmium (Cd) and zinc ( $\mathrm{Zn}$ ) phytoextraction are still poorly understood, as are the effects of nitrogen fertilizers. We studied biomass production and $\mathrm{Cd}$ and $\mathrm{Zn}$ uptake by two contrasting populations of $N$. caerulescens, Ganges (metallicolous) and Wilwerwiltz (non-metallicolous) grown in pots on a range of 24 field contaminated soils for 20 weeks. The addition of $\mathrm{KNO}_{3}$ and $\mathrm{NH}_{4} \mathrm{NO}_{3}$ fertilizers was also tested. Using model averaging of multiple regression models, we show that the major drivers of $N$. caerulescens growth are physical soil factors such as organic matter and soil bulk density while trace metal accumulation mainly relies on soil $\mathrm{Cd}$ and $\mathrm{Zn}$ exchangeable concentrations. We confirm the negative effect of soil copper (Cu) on growth, even at exchangeable concentrations below $30 \mathrm{mg} \mathrm{kg}^{-1}$, and therefore on uptake efficiency, while increasing soil lead $(\mathrm{Pb})$ content was related to increased biomass probably due to a protective effect against soil pathogens. Finally, there is a small positive effect of nitrogen fertilization on biomass production only in soils with low initial nitrogen content (under $25 \mu \mathrm{g} \mathrm{g}^{-1} \mathrm{NO}_{3}^{-}$), while above this value, the positive impact of initial nitrogen content is offset by lower shoot $\mathrm{Cd}$ and $\mathrm{Zn}$ concentrations. Our data bring substantial information regarding the physico-chemical properties to ensure $N$. caerulescens growth: a soil bulk density under $1.05 \mathrm{~kg} / \mathrm{dm}^{3}$, organic matter above $7 \%$ and $\mathrm{pH}$ under 7.5 . We show that phytoextraction efficiency is maximal for moderate soil contamination in $\mathrm{Cd}\left(2-10 \mathrm{mg} \mathrm{kg}^{-1}\right)$ and $\mathrm{Zn}\left(300-1000 \mathrm{mg} \mathrm{kg}^{-1}\right)$.

(C) 2019 Elsevier B.V. All rights reserved.

\footnotetext{
* Corresponding author.

E-mail address: arjacobs@ulb.ac.be (A. Jacobs).
}

\section{Introduction}

Noccaea caerulescens (J. Presl \& C. Presl) F.K. Mey is a cadmium (Cd), zinc $(\mathrm{Zn})$ and nickel $(\mathrm{Ni})$ hyperaccumulator, well known to be a 
model species for the study of metal tolerance, homeostasis and hyperaccumulation (Assunção et al., 2003; Krämer, 2010). It is also considered a good candidate for $\mathrm{Cd}$ and/or $\mathrm{Zn}$ phytoextraction of soils with moderate contamination and has been tested numerous times in the field (Hammer and Keller, 2003; Jacobs et al., 2017, 2018a, b; Maxted et al., 2007; McGrath et al., 2006; Schwartz et al., 2003). In field trials large differences in biomass production of $N$. caerulescens were recorded between sites and plots within and among studies, sometimes by a factor of 5 (from 0.74 to $3.65 \mathrm{t} \mathrm{ha}^{-1}$ in McGrath et al., 2006, from 1.5 to $4 \mathrm{t} \mathrm{ha}^{-1}$ in Maxted et al., 2007 and from 1 up to $5 \mathrm{t} \mathrm{ha}^{-1}$ in Jacobs et al., 2017, 2018a). This results from differences of populations used, in cultural practices, meteorological conditions and length of growth between studies, but also to large differences in soil characteristics. Edaphic factors are also well-known to influence soil metal bioavailability (Alloway, 2012), and therefore accumulation levels in hyperaccumulator plants (Keller and Hammer, 2004; Yanai et al., 2006). This overall variability makes phytoextraction efficiency poorly predictable.

Efficiency of metal extraction depends on both shoot metal concentrations and plant biomass, the second being often neglected. Most of our knowledge on the influence of the natural variation of soil parameters on $N$. caerulescens biomass production is restricted to the influence of $\mathrm{pH}$, and soil $\mathrm{Cd}$ and $\mathrm{Zn}$ to a minor extent (Maxted et al., 2007; Wang et al., 2006; Yanai et al., 2006). Yanai et al. (2006) found that at very acidic soil $\mathrm{pH}$ (4.4), N. caerulescens (Ganges population) showed a strong reduction of growth. In another study, Wang et al. (2006) showed that $N$. caerulescens growth was highest at the low soil $\mathrm{pH}(4.7)$ with high soil contamination (25.4 and $1500 \mathrm{mg} \mathrm{kg}^{-1}$, of $\mathrm{Cd}$ and $\mathrm{Zn}$ ), and at intermediate soil pH (6.1) with lower soil contamination (5 and $450 \mathrm{mg} \mathrm{kg}^{-1}$ ). Noccaea caerulescens growth is stimulated by the presence of metals as a certain physiological need in $\mathrm{Cd}$ and/or $\mathrm{Zn}$ has been demonstrated previously for metallicolous (MET) populations, mostly Ganges (Escarré et al., 2000; Pongrac et al., 2009; Yanai et al., 2006), and in one case for non-metallicolous (NMET) populations (Jacobs et al., 2017). It has been shown that $N$. caerulescens has an elevated $\mathrm{Zn}$ deficiency threshold due to enhanced vacuolar sequestration which could explain a higher physiological need (Shen et al., 1997). It is also known that an excess in soil copper $(\mathrm{Cu})$ can reduce $N$. caerulescens growth, probably due to an inhibition of iron ( $\mathrm{Fe}$ ) transport (Lombi et al., 2001b; McGrath et al., 2006; Walker and Bernal, 2004). Finally, N. caerulescens mostly grows on rocky shallow soils with good drainage in Belgium and Luxembourg (Dechamps et al., 2008; Meerts and Grommesch, 2001; Molitor et al., 2005) and in the Swiss Jura (Basic et al., 2006) which suggests some preference for an aerated soil structure.

Metal uptake by N. caerulescens has been more studied than its biomass production but most studies have so far also mostly concentrated on the soil metal load and variation in pH (Maxted et al., 2007; McGrath et al., 2001, 2006; Wang et al., 2006; Yanai et al., 2006; Zhao et al., 2003). Two studies found that $\mathrm{Cd}$ and $\mathrm{Zn}$ uptake were maximum at soil $\mathrm{pH}$ between 5 and 6 (Wang et al., 2006; Yanai et al., 2006). With the "Ganges" population, Yanai et al. (2006) showed that total Cd and $\mathrm{Zn}$ and soil pH were the best predictors of $\mathrm{Cd}$ and $\mathrm{Zn}$ concentrations and uptake on a large range of soil Cd concentrations while clay and organic carbon also explained some of the variation. Based on pot and field trials with Ganges plants, Maxted et al. (2007) presented a model of Cd uptake depending on $\mathrm{Cd}$ free ion activity in the soil solution calculated with total soil Cd, pH and soil organic carbon. Rosenfeld et al. (2018) recently highlighted the impact of soil geochemical factors (such as Fe oxide or sulfur solid phases) in addition to soil $\mathrm{Cd}$ and $\mathrm{pH}$ on $\mathrm{N}$. caerulescens $\mathrm{Cd}$ uptake in four contaminated soils. Furthermore, multiple positive and negative interactions between soil trace metals of interest ( $\mathrm{Cd}, \mathrm{Zn}$ ) and others $(\mathrm{Cu}, \mathrm{Fe})$ influence $N$. caerulescens uptake (Lombi et al., 2002; Tolrà et al., 1996; Walker and Bernal, 2004) but little is known about the overall effect on phytoextraction efficiency. There is therefore a large interest in understanding the influence of other major chemical and physical properties of the soil on $N$. caerulescens growth and to rank the relative importance of soil properties in the influence of total metal uptake, i.e. phytoextraction efficiency.

It is commonly accepted that one easy way to enhance aboveground biomass production of plants is through nitrogen $(\mathrm{N})$ fertilization. All pot and field studies have shown a positive effect of $\mathrm{N}$ fertilization on $N$. caerulescens growth (Bennett et al., 1998; Schwartz et al., 2003; Sirguey et al., 2006; Monsant et al., 2008; Xie et al., 2009; Jacobs et al., 2018a). Nevertheless, $\mathrm{N}$ fertilization also results in lower $\mathrm{Cd}$ and $\mathrm{Zn}$ shoot concentrations due to metal dilution in leaves and/or competition with the $\mathrm{N}$ fertilizers in the rhizosphere, with a stronger effect with $\mathrm{NH}_{4}^{+}$than $\mathrm{NO}_{3}^{-}$(Monsant et al., 2008, Xie et al., 2009, Jacobs et al., 2018a). All in all, $\mathrm{N}$ input increases trace metal uptake only at high doses (80-150 $\mathrm{mg} \mathrm{N} \mathrm{kg}^{-1}$ dry soil), while at lower doses of $\mathrm{N}$ (30 $\mathrm{mg} \mathrm{N} \mathrm{kg}^{-1}$ ) it has no positive effect on metal uptake. In the field, $\mathrm{N}$ addition was either positive in favorable growth conditions, or neutral to slightly negative in unfavorable growth conditions (high $\mathrm{pH}$ and high soil density) (Jacobs et al., 2018a). We hypothesize that the effect of $\mathrm{N}$ fertilization will depend mostly on the initial $\mathrm{N}$ content and potentially on other soil fertility parameters like initial available P content.

To improve the predictability of phytoextraction, we conducted a pot trial with two contrasting populations of $N$. caerulescens for 20 weeks on 24 field soils with moderate contamination, representative of the Belgian contaminated soils where phytoextraction could be applicable. Soils were characterized by $>20$ physico-chemical variables and data were analyzed by means of model averaging of multiple regression models which allows for more robust inference than traditional stepward model selection. We also compared the effect of two different $\mathrm{N}$ treatments, $\mathrm{NH}_{4} \mathrm{NO}_{3}$ and $\mathrm{KNO}_{3}$, as it has been suggested that $N$. caerulescens may react more strongly to $\mathrm{NO}_{3}^{-}$(Schwartz et al., 2003; Sirguey et al., 2006). The objectives of the present study were 1) to investigate the effects of soil metals and physico-chemical characteristics and 2) to test the effect of moderate $\mathrm{N}$ fertilization, on $N$. caerulescens growth and metal uptake, assessed for two contrasting ecotypes on a wide range of field contaminated soils.

\section{Material and methods}

\subsection{Soil sampling and analysis}

Soils were collected in 24 sites (urban wastelands, nature reserves, collective and private gardens) in Brussels and Wallonia (Belgium). Sites were chosen based on a recorded trace metal contamination or based on the knowledge of a former soil use at risk according to the Belgian legislation (e.g. workshops for motor vehicle or metal working, printing industry, pesticide storage). Topsoil properties of the sites studied cover the range of soil pH, organic matter content (OM, \%) and total trace metal concentrations reported for the French urban vegetable gardens (Joimel et al., 2016), but present systematic higher maximum values for total trace metal concentrations with factors of 20,13,2 and 6 for $\mathrm{Cd}, \mathrm{Zn}, \mathrm{Cu}$, and $\mathrm{Pb}$, respectively. On each site the soil was taken to $30 \mathrm{~cm}$ depth; 5 subsamples were brought together to form a composite. Soils were homogenized with a rotary sieve (Scheppach ${ }^{\circledR}$ RS 400) and the coarse fraction $(>5 \mathrm{~mm}$ ) was removed. General site and soil characteristics are shown in Table 1 , while detailed soil physicochemical properties can be found in Table S1.

Soil characterization was carried out following standard protocols of soil analysis (Pansu and Gautheyrou, 2006). Soil samples were air-dried and sieved through a $2 \mathrm{~mm}$ sieve. The remaining fraction $(2<\mathrm{d}<5 \mathrm{~mm})$ was estimated as the gravel charge of the soil (GC). Soil pH- $\mathrm{H}_{2} \mathrm{O}$ was measured using glass electrodes in a 1:5 soil:water suspension. Organic matter content was measured by loss on ignition at $500{ }^{\circ} \mathrm{C}$. The cation exchange capacity (CEC, $\mathrm{cmol}_{\mathrm{c}} \mathrm{kg}^{-1}$ ) was measured on a soil extract with cobaltihexamine trichloride according to ISO 23470:2007. Total element concentrations were measured on a tri-acid $\left(\mathrm{HCl} 37 \%, \mathrm{HNO}_{3} 65 \%\right.$, HF $40 \%$ ) dissolution of finely ground soil samples $(200 \mu \mathrm{m})$ on a hot 
Table 1

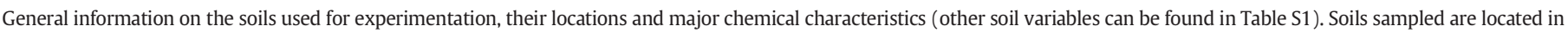

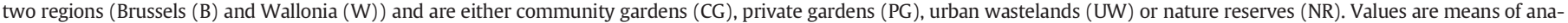
lytical triplicates, and trace metal concentrations in bold are above legal thresholds in Brussels or Wallonia (for each element, the lower threshold is chosen).

\begin{tabular}{|c|c|c|c|c|c|c|c|c|c|c|c|c|c|}
\hline \multirow[t]{2}{*}{ Soil } & \multirow[t]{2}{*}{$\begin{array}{l}\text { Location } \\
\text { (Region, type of site) }\end{array}$} & \multirow[t]{2}{*}{$\mathrm{pH}$} & \multirow[t]{2}{*}{$\mathrm{OM}(\%)$} & \multirow[t]{2}{*}{$\mathrm{N}-\mathrm{NO}_{3}\left(\mathrm{mg} \mathrm{kg}^{-1}\right)$} & \multirow[t]{2}{*}{$\mathrm{N}-\mathrm{NH}_{4}\left(\mathrm{mg} \mathrm{kg}^{-1}\right)$} & \multicolumn{4}{|c|}{$\begin{array}{l}\text { Total concentrations } \\
\left(\mathrm{mg} \mathrm{kg}^{-1}\right)\end{array}$} & \multicolumn{4}{|c|}{$\begin{array}{l}\text { Exchangeable }{ }^{\mathrm{b}} \text { concentrations } \\
\left(\mathrm{mg} \mathrm{kg}^{-1}\right)\end{array}$} \\
\hline & & & & & & $\mathrm{Cd}$ & $\mathrm{Cu}$ & $\mathrm{Pb}$ & $\mathrm{Zn}$ & $\mathrm{Cd}$ & $\mathrm{Cu}$ & $\mathrm{Pb}$ & $\mathrm{Zn}$ \\
\hline ALST & Laeken (B, CG) & 6.61 & 20.2 & 187 & 0.72 & 1.4 & 141 & 222 & 334 & 0.70 & 42 & 70 & 151 \\
\hline AN1 & Anderlecht (B, UW) & 7.24 & 8.0 & 420 & 0.77 & 0.6 & 26 & 103 & 126 & 0.46 & 7 & 48 & 44 \\
\hline AN2 & Anderlecht (B, UW) & 7.68 & 4.1 & 0.9 & 0.13 & 1.0 & 49 & 572 & 217 & 0.36 & 14 & 290 & 40 \\
\hline AN3 & Anderlecht (B, UW) & 7.69 & 5.4 & 0.8 & 0.85 & 1.0 & 73 & 301 & 228 & 0.89 & 52 & 295 & 91 \\
\hline AN4 & Anderlecht (B, UW) & 7.85 & 4.5 & 1.0 & 0.48 & 1.2 & 94 & 473 & 226 & 0.35 & 29 & 195 & 36 \\
\hline ANG & Angleur (W, PG) & 6.82 & 13.6 & 5.4 & 9.24 & 3.7 & 107 & 719 & 1700 & 3.01 & 38 & 209 & 730 \\
\hline BEM & Forest $(\mathrm{B}, \mathrm{CG})$ & 7.13 & 6.0 & 66 & 1.63 & 1.2 & 49 & 182 & 227 & 0.91 & 18 & 72 & 104 \\
\hline CHA1 & Châtelet (W, PG) & 7.00 & 16.6 & 7.5 & 1.75 & 1.7 & 86 & 247 & 592 & 0.76 & 19 & 66 & 177 \\
\hline $\mathrm{CHA} 2$ & Châtelet (W, PG) & 7.24 & 19.9 & 2.0 & 0.67 & 1.2 & 84 & 419 & 479 & 0.58 & 13 & 103 & 164 \\
\hline FLO & Flône (W, PG) & 6.96 & 9.4 & 13.5 & 28.6 & 6.2 & 32 & 198 & 1460 & 5.41 & 10 & 121 & 730 \\
\hline GR & Laeken (B, UW) & 6.76 & 19.9 & 858 & 1.07 & 1.3 & 94 & 279 & 315 & 0.87 & 33 & 113 & 127 \\
\hline GRAY & Ixelles (B, CG) & 7.63 & 5.6 & 27.4 & 0.76 & 1.3 & 172 & 262 & 2390 & 0.61 & 80 & 120 & 830 \\
\hline LIE & Liège (W, PG) & 6.24 & 16.9 & 6.2 & 28.9 & 20.0 & 240 & 841 & 5320 & 13.86 & 101 & 383 & 3200 \\
\hline MAS & Brussels (B, UW) & 8.01 & 5.0 & 39.1 & 0.52 & 1.6 & 205 & 287 & 427 & 0.67 & 39 & 94 & 51 \\
\hline MOE1 & Evere (B, NR) & 6.84 & 10.5 & 174 & 0.43 & 2.0 & 70 & 1480 & 2650 & 1.37 & 24 & 580 & 850 \\
\hline MOE2 & Evere (B, NR) & 7.18 & 8.7 & 750 & 2.29 & 1.0 & 26 & 1410 & 209 & 0.37 & 7 & 710 & 75 \\
\hline NAV & Schaerbeek (B, CG) & 7.47 & 7.0 & 3.2 & 0.40 & 1.3 & 110 & 263 & 278 & 0.50 & 46 & 102 & 76 \\
\hline RUE & Molenbeek (B, CG) & 7.93 & 4.3 & 0.8 & 0.38 & 1.1 & 28 & 152 & 188 & 0.17 & 7 & 47 & 30 \\
\hline SER1 & Seraing (W, PG) & 7.20 & 13.5 & 2.1 & 1.03 & 2.8 & 88 & 412 & 735 & 1.52 & 23 & 114 & 232 \\
\hline SER2 & Seraing (W, PG) & 6.95 & 13.3 & 19.7 & 1.33 & 2.6 & 69 & 181 & 597 & 1.64 & 16 & 72 & 235 \\
\hline SOL6 & Vaux-sous-Chèvremont (W, PG) & 7.35 & 9.8 & 1.3 & 0.93 & 3.0 & 53 & 154 & 584 & 1.91 & 16 & 59 & 180 \\
\hline TIL & Uccle (B, CG) & 6.26 & 4.4 & 83 & 1.44 & 0.6 & 29 & 92 & 75 & 0.29 & 17 & 68 & 48 \\
\hline TIN & Tinlot (W, PG) & 7.01 & 7.5 & 1.2 & 4.12 & 1.6 & 40 & 525 & 593 & 0.82 & 13 & 175 & 247 \\
\hline \multirow[t]{3}{*}{ WIE } & Forest (B, CG) & 7.82 & 8.1 & 0.9 & 0.46 & 0.9 & 84 & 301 & 307 & 0.21 & 18 & 56 & 51 \\
\hline & MIN & 6.24 & 4.1 & 0.8 & 0.13 & 0.6 & 26 & 92 & 75 & 0.17 & 7 & 47 & 30 \\
\hline & MAX & 8.01 & 20.2 & 858 & 28.9 & 20 & 240 & 1480 & 5320 & 13.86 & 101 & 710 & 3200 \\
\hline \multirow{2}{*}{\multicolumn{5}{|c|}{ Legal intervention thresholds for agricultural soils ${ }^{c}$}} & Brussels & 2 & 120 & 200 & 333 & & & & \\
\hline & & & & & Wallonia & 10 & 145 & 400 & 300 & & & & \\
\hline
\end{tabular}

\footnotetext{
a Tri-acid dissolution.

b EDTA-NH $_{4}^{+}$acetate extraction.

c Based on aqua regia dissolution.
}

plate at $70{ }^{\circ} \mathrm{C}$ for $48 \mathrm{~h}$. The dry residue was re-dissolved with $1 \mathrm{mLHNO}_{3}$ $65 \%$ in a volume of $30 \mathrm{~mL}$ and total element concentrations were determined by inductively coupled plasma emission spectrometry (ICP-OES) (Varian Vista-MPX) and checked with a certified reference soil material (SRM 2711a, Montana II Soil). Exchangeable cations (Al, Ca, Cd, Cu, Fe, K, $\mathrm{Mg}, \mathrm{Mn}, \mathrm{Ni}, \mathrm{Pb}, \mathrm{Zn}$ ) were extracted with ammonium acetate $0.5 \mathrm{M}$-EDTA $0.02 \mathrm{M}$ at pH 7 (Cottenie et al., 1979) and their concentrations were measured by ICP-OES (Varian Vista-MPX). Soil texture (percentage of clay, silt and sand) was determined using wet sieving and the pipette method after $\mathrm{OM}$ destruction with $\mathrm{H}_{2} \mathrm{O}_{2}$ and $\mathrm{Na}$ citrate dispersion of clay. Undisturbed soil cores were taken after cultivation for soil bulk density (BD) measurement (cylinder method). A water permeability index (PI) was measured as the infiltration speed of $50 \mathrm{~mL}$ water over $6 \mathrm{~h}$ in undisturbed soil cores previously watered to water-holding capacity. A carbonate index (CARB) was determined by a simple reaction to $10 \% \mathrm{HCl}$ with a binary response: 0 (no or very weak reaction) or 1 (strong visual reaction). Mineral $\mathrm{NO}_{3}^{-}$and $\mathrm{NH}_{4}^{+}$exchangeable concentrations were measured on $1 \mathrm{M} \mathrm{KCl}$ extract of fresh soil samples collected in pots before the first $\mathrm{N}$ application by the sulphanilamide colorimetric method for $\mathrm{NO}_{3}^{-}$and indophenol blue method for $\mathrm{NH}_{4}^{+}$, and were expressed in units of $\mathrm{N}\left(\mathrm{N}-\mathrm{NO}_{3}\right.$ and $\mathrm{N}-\mathrm{NH}_{4}$ in $\left.\mathrm{mg} \mathrm{kg}^{-1}\right)$.

\subsection{Pot experiment and plant analysis}

Plastic pots of $500 \mathrm{~cm}^{3}$ were filled with $400 \mathrm{~g}$ of air-dried soil mixed with $150 \mathrm{~g}$ of quartz gravel $(6-12 \mathrm{~mm})$ to maintain aeration and limit compaction. Our aim in adding this gravel fraction was to avoid artificial compaction of soils that had previously been sieved. The presence of this coarse material did not affect the soil variables measured on the fine fraction $(<2 \mathrm{~mm})$. Plants were grown from seeds for two months in trays filled with commercial garden compost placed on a sheltered terrace. Seedlings were transplanted in early April 2017 at the fourto-six leaves stage in 516 pots with contaminated soils ( 24 soils $\times 2$ populations $\times 3$ treatments $\times 3-4$ replicates). To avoid any fertilizer or metal leaching, we put all replicates of the same soil and fertilizer treatment in the same watering tray. To avoid local environmental effect in the unheated plastic greenhouse, we randomized watering trays every two weeks. Two populations of Noccaea caerulescens, one metallicolous (MET) from Ganges, hereafter GAN (village of SaintLaurent-le-Minier, South of France), and one non-metallicolous (NMET) from Luxembourg, hereafter LUX (village of Wilwerwiltz) were used. After two weeks, dead plants were replaced (post-transplantation mortality). Nitrogen treatment $\left(\mathrm{NH}_{4} \mathrm{NO}_{3}\right.$ or $\mathrm{KNO}_{3}$, in solution) was added for the first time one month after transplantation and then every three weeks (each time $10 \mathrm{mg} \mathrm{N} \mathrm{kg}^{-1}$ dry soil (DS) for a total of $40 \mathrm{mg} \mathrm{N} \mathrm{kg}^{-1} \mathrm{DS}$ ) while no $\mathrm{N}$ was added to control pots. Plants were watered every week with distilled water. Pychlorex (chlorpyriphos 5\%) was applied once in all pots following an invasion of sciarid flies larvae. All flower stalks were cut off the first week of June and August to promote vegetative growth.

After 20 weeks of growth aboveground plant parts were harvested, including leaves (i.e. vegetative biomass) and flower stalks (i.e. reproductive biomass). Mortality was estimated as the number of dead plants at the end of the experiment. Plants were thoroughly washed with tap water and rinsed with deionized water. Reproductive and vegetative biomass of $65{ }^{\circ} \mathrm{C}$ oven-dried plants was measured. For each plant, reproductive and vegetative parts were ground together with a Retsch ZM100 mill and subsamples of $0.4 \mathrm{~g}$ were dry-ashed for $12 \mathrm{~h}$ at $450{ }^{\circ} \mathrm{C}$ and dissolved with concentrated $\mathrm{HNO}_{3}$ (65\%). Plant concentrations in trace metals $(\mathrm{Cd}, \mathrm{Cu}, \mathrm{Ni}, \mathrm{Pb}, \mathrm{Zn}$ ) macro- and micronutrients (calcium: $\mathrm{Ca}$, magnesium: $\mathrm{Mg}$, potassium: $\mathrm{K}$, phosphorus: $\mathrm{P}$, iron: $\mathrm{Fe}$, and manganese: $\mathrm{Mn}$ ) - expressed as $\mu \mathrm{g} \mathrm{g}^{-1}$ of $105^{\circ} \mathrm{C}$-dried plant - were measured 
by ICP-OES (Varian, Vista MPX). Method accuracy was checked with NIST standard reference (SRM 1547, Peach leaves) and an in-house standard. Plant metal uptake (expressed in $\mu$ g plant ${ }^{-1}$ ) was calculated as the product of plant biomass and shoot $\mathrm{Cd}$ or $\mathrm{Zn}$ concentrations.

\subsection{Statistical analysis}

Plant and soil variables were transformed using the Box-Cox function prior to all analyses to linearize relations among explanatory and dependent variables. The variations in biomass production (vegetative and reproductive) and $\mathrm{Cd}$ and $\mathrm{Zn}$ concentrations and uptake were analyzed by means of three-way analysis of variance to investigate the effects of soil, $\mathrm{N}$ treatments $\left(\mathrm{NH}_{4} \mathrm{NO}_{3}\right.$ or $\left.\mathrm{KNO}_{3}\right)$ and population (GAN and LUX). We conducted analyses of covariance of biomass production to test the interaction between initial soil $\mathrm{N}$ content $\left(\mathrm{N}-\mathrm{NH}_{4}\right.$ and $\mathrm{N}-\mathrm{NO}_{3}$ as covariables) and the treatment effect. Data transformation and analysis of variance were performed using the package 'car' in $\mathrm{R}$ (Fox et al., 2011).

To determine which soil factors influence the most biomass production, shoot metal concentrations and metal uptake, we used a model averaging approach (Burnham and Anderson, 2002) to construct a linear regression model based on data obtained on the control treatment. In this model, we used as predictor variables exchangeable concentrations in trace metals and macronutrients instead of total concentrations because: 1) the former are more representative of short term availability and informative for plant-soil interactions, and 2) metal uptake by $N$. caerulescens is better explained by labile or exchangeable trace metal concentrations (Hutchinson et al., 2000; Knight et al., 1997; Sterckeman et al., 2004). The CARB variable was considered as a quantitative discontinuous variable. Such binary descriptor can be used in principal component analysis or regression analysis models (Legendre and Legendre, 2012). First, we conducted a selection among the 22 soil variables measured to reduce collinearity to a maximum correlation of 0.7 between two variables using the vifcor function in package usdm (Naimi et al., 2014). One exception was made for soil $\mathrm{Cd}$ and $\mathrm{Zn}$ exchangeable concentrations which were both kept for further analysis despite their correlation ( $r=0.85)$. We scaled and centred the 16 remaining selected soil variables to allow for comparison between variable estimates. All possible linear models were constructed using a combination of the selected soil variables as explanatory variables (with a maximum of 10 variables in each model), to account for biomass production, shoot $\mathrm{Cd}$ and $\mathrm{Zn}$ concentrations, and $\mathrm{Cd}$ and $\mathrm{Zn}$ uptake. The models were first ranked according to their corrected Akaike Information Criterion (AICc). Model averaging was performed with the function model.select (for similar use, see Simon-Delso et al., 2017) using shrinkage averaging over all possible models to calculate AICc weights of importance, average coefficients and unconditional standard errors for each variable (Burnham and Anderson, 2002). This method shrinks the average coefficients towards 0 for variables mostly present in the poorly supported models. The AICc variable weights (i.e. the probability for a given variable to be present in the best model if data is resampled) enable the comparison of relative importance of variables. A reasonable minimum threshold of 0.7 of AICC variable weight was chosen as a criterion to interpret only the most important variables. Results were confirmed by a second method from the glmulti package which conducts model averaging over the 100 best models (i.e. with the lowest AICc) with an iterative algorithm (Calcagno and de Mazancourt, 2010). All statistical analyses were conducted with the R statistical software v 3.4.4 (R Development Core Team, 2018).

\section{Results}

3.1. Growth and metal accumulation on 24 unfertilized soils: differences between populations

The average survival rate on the 24 control soils was $89 \%$, most of the mortality being probably due to pests (sciarid flies larvae, personal observation). Average biomass production, shoot macronutrients and trace metal concentrations on the 24 control soils can be found in Table S2. After 20 weeks, average aboveground plant biomass on the control soil (without $\mathrm{N}$ fertilization) was $1.08 \mathrm{~g}$ (LUX $1.12 \mathrm{~g}$ and GAN $1.04 \mathrm{~g}, p>0.05$ ) and ranged across soils from $0.21 \mathrm{~g}$ (RUE) to $3.3 \mathrm{~g}$ (GR) (Fig. 1). GAN plants produced on average more reproductive biomass

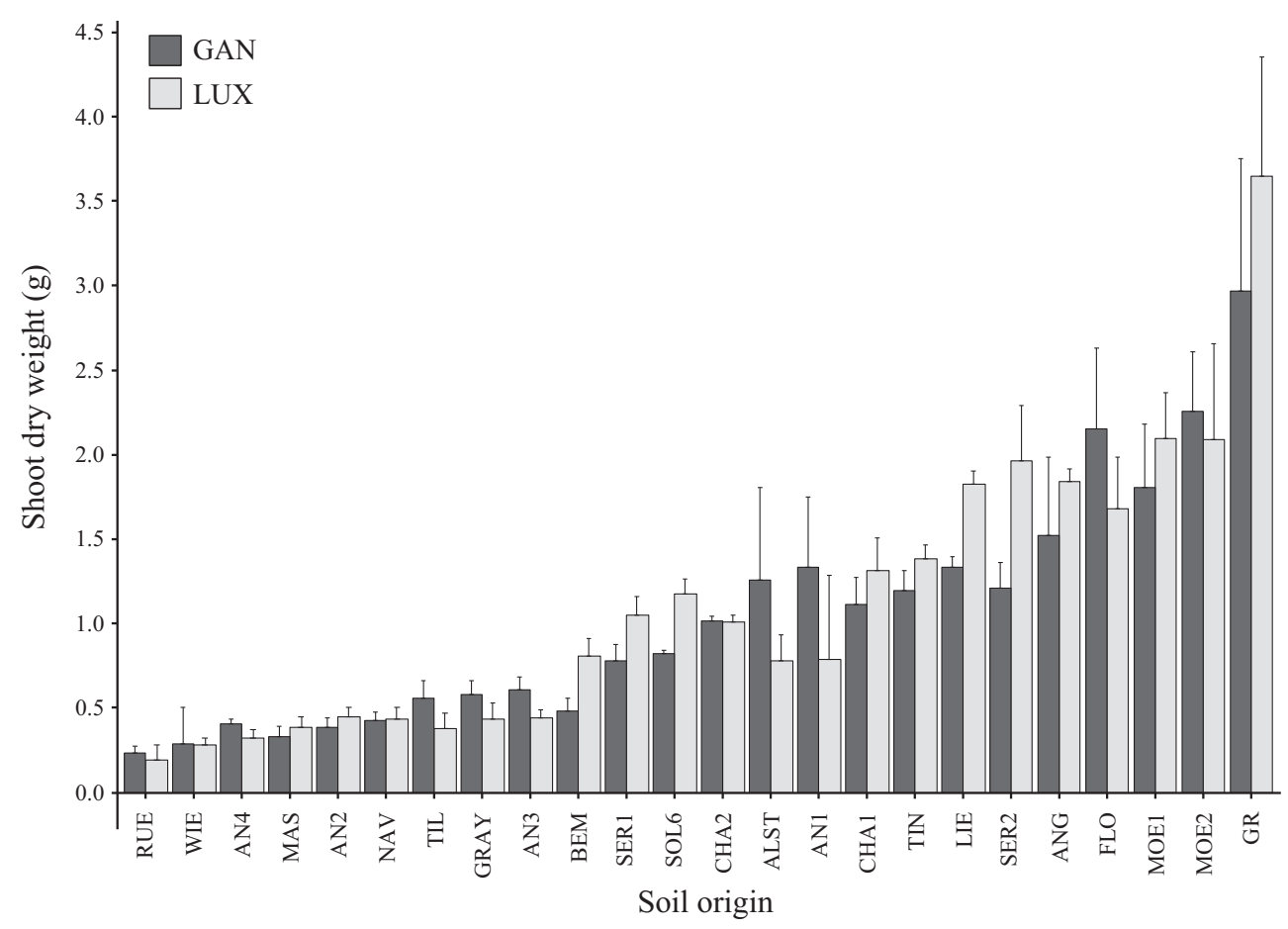

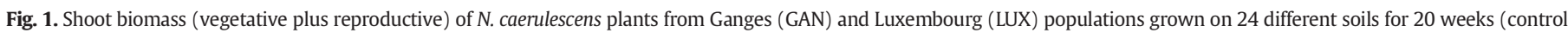
treatment). Data are means + standard errors $(n=2-4$ plants per population $\times$ soil $)$, ranked by increasing mean values of both populations. 

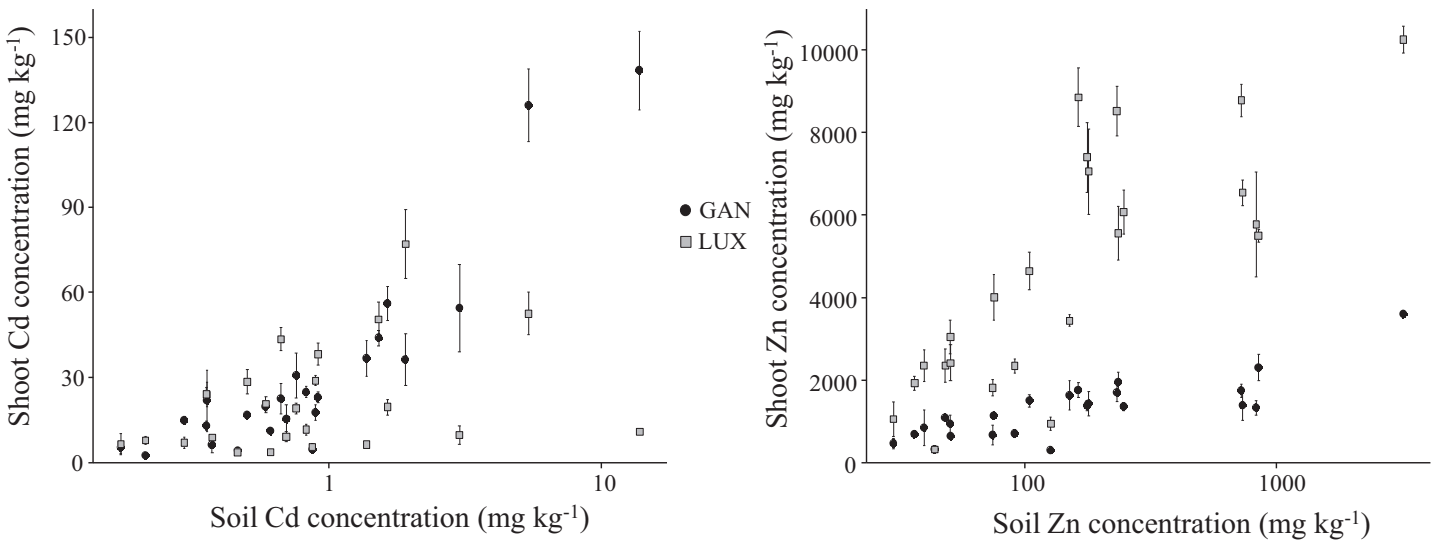

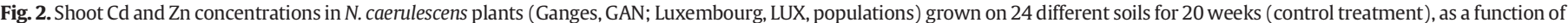
soil $\mathrm{Cd}$ and $\mathrm{Zn}$ exchangeable concentrations (EDTA-NH 4 acetate) (logarithmic scale). Data are means \pm standard errors $(n=2-4$ plants per population $\times$ soil).

(flower stalks) $(0.37 \mathrm{~g})$ than $\operatorname{LUX}(0.13 \mathrm{~g})(p<0.001)$, whereas vegetative biomass of GAN plants $(0.68 \mathrm{~g})$ was lower than LUX $(0.99 \mathrm{~g})(p<0.001)$ (Table S3).

As expected, shoot $\mathrm{Cd}$ concentrations were overall higher in GAN plants $\left(31 \mu \mathrm{g} \mathrm{g}^{-1}\right.$, ranging from 3 to $\left.138 \mu \mathrm{g} \mathrm{g} \mathrm{g}^{-1}\right)$ than in LUX plants (22 $\mu \mathrm{g} \mathrm{g}{ }^{-1}$, ranging from 4 to $\left.77 \mu g g^{-1}\right)(p<0.001)$, the difference being more pronounced on soils with higher contamination (Fig. 2). Conversely shoot $\mathrm{Zn}$ concentrations were significantly higher in LUX plants $\left(4290 \mu \mathrm{g} \mathrm{g}^{-1}\right.$, from 320 to $10,250 \mu \mathrm{g} \mathrm{g}^{-1}$ ) than in GAN plants $\left(1250 \mu \mathrm{g} \mathrm{g}^{-1}\right.$, from 300 to $3600 \mu \mathrm{g} \mathrm{g}^{-1}$ ) on all soils $(p<0.001)$ (Fig. 2 ).

Correlations between macronutrient and trace metal concentrations in shoots were calculated at the species and population levels on the control (only significant correlations with $|r|>0.3$ are indicated). For shoot macronutrients there was a significant correlation between $\mathrm{Ca}$ and $\mathrm{Mg}(r=0.36)$ and $\mathrm{K}$ and $\mathrm{P}(r=0.40)$ at the species level. For trace metals, $\mathrm{Cd}, \mathrm{Zn}$ and Ni were correlated (Cd-Zn: $r=0.40$, Cd-Ni: $r=0.45, \mathrm{Zn}-\mathrm{Ni}: r=0.43)$. Correlations were stronger and not always of the same nature when considering populations separately: for GAN, Ca and $\mathrm{Mg}(r=0.55), \mathrm{K}$ and $\mathrm{P}(r=0.65), \mathrm{Cd}$ and $\mathrm{Zn}$ $(r=0.80), \mathrm{Cd}$ and $\mathrm{Mn}(r=0.50)$ and $\mathrm{Ni}$ and $\mathrm{Cu}(r=0.44)$; for $\mathrm{LUX}$, $\mathrm{K}$ and $\mathrm{P}(r=0.50), \mathrm{Cd}$ and $\mathrm{Zn}(r=0.51), \mathrm{Cd}$ and $\mathrm{Ni}(r=0.74)$, Ni and $\mathrm{Cu}(r=0.48), \mathrm{Zn}$ and $\mathrm{Mn}(r=0.56)$.

\subsection{Influence of soil parameters}

The influence of soil parameters on biomass production and metal accumulation was assessed by means of a selection of linear models with model averaging performed on the two populations separately. A principal component analysis was performed to synthesize the explanatory dataset (Fig. S4). Three groups of collinear soil variables (correlation $r>0.7$ ) were identified in the dataset, and only one variable per group was kept as explanatory variable for model selection and chosen to minimize collinearity with other variables: $\mathbf{O M}$ which was correlated with CEC and BD was kept, Sand with Silt and Clay, Fe with pH and Al. A threshold of AICc variable weight of importance $w>0.7$ was set to identify the most important explanatory variables significantly supported by the models; for instance, a factor with a $\mathrm{w}=0.95$ was kept in $95 \%$ of the 100 best regression models.

For biomass production, selected soil explanatory variables were the same for both populations. Coefficient estimates (in parentheses) indicate the magnitude and the sign of the effect on the response variable. Organic matter content (GAN 0.3, LUX 0.38), Pb (GAN 0.32, LUX 0.36) and initial $\mathrm{N}^{-\mathrm{NO}_{3}}$ (GAN 0.3, LUX 0.24 ) positively influenced biomass production while $\mathrm{Cu}$ (GAN -0.18, LUX -0.12) and Sand (GAN -0.19, LUX -0.18) had a negative influence (Fig. 3). In order to rule out

\section{BIOMASS}
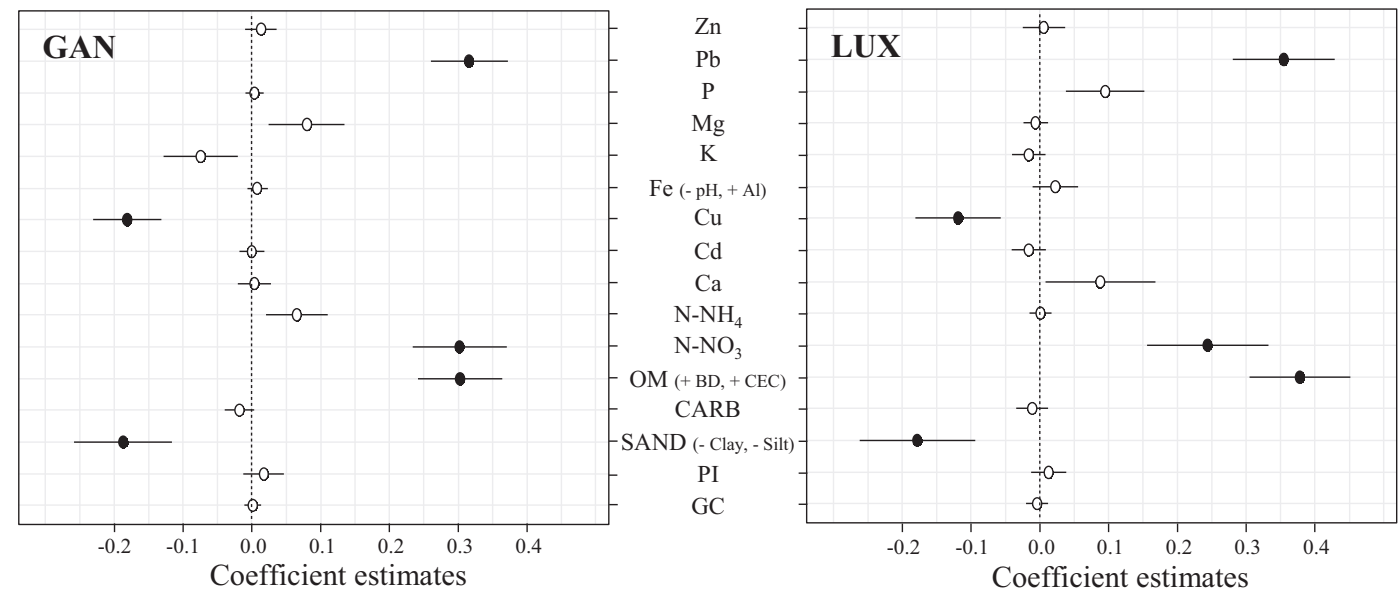

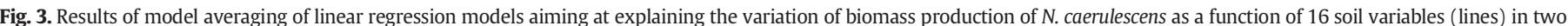

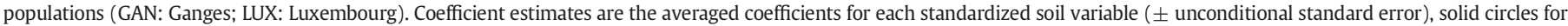

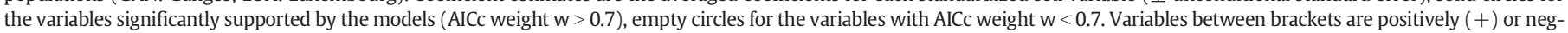
atively $(-)$ correlated $(|r|>0.7)$ to the variable retained in model selection. CARB $=$ Carbonate index, PI $=$ Permeability index, GC $=$ Gravel charge. 
potential effects of outliers and interpret with confidence the effect of $\mathrm{Pb}$, we performed new model selection without three soils with extreme $\mathrm{Pb}$ and $\mathrm{Zn}$ values (LIE, MOE1 and MOE2) and the results were mostly similar (Table S4). Effect curves of the selected variables enable to show that the effect of some variables occurred mostly in a specific range - between 0 and $50 \mathrm{mg} \mathrm{kg}^{-1}$ for $\mathrm{N}-\mathrm{NO}_{3}, 0$ and $300 \mathrm{mg} \mathrm{Pb} \mathrm{kg}{ }^{-1}$ and 0 and $30 \mathrm{mg} \mathrm{Cu} \mathrm{kg}^{-1}$ - while for OM and Sand the effect was almost linear (Fig. S1).

Shoot Cd concentrations were mainly explained by soil Cd for both populations (GAN 1.19, LUX 1.81) (Fig. 4). A negative influence of initial $\mathrm{N}-\mathrm{NO}_{3}$ on shoot $\mathrm{Cd}$ concentrations was highlighted for both populations (GAN -0.32, LUX -0.45). In LUX plants, shoot Cd concentration was also negatively influenced by soil $\mathrm{Zn}(-0.98)$, and to a minor extent by gravel charge $(\mathrm{GC} ;-0.36)$ and $\mathrm{Pb}(-0.26)$. In GAN plants the CARB index $(-0.25)$ and $\mathrm{Ca}(-0.23)$ had a small negative influence on $\mathrm{Cd}$ accumulation.

Shoot $\mathrm{Zn}$ concentration was also mainly influenced by soil Zn (GAN 0.43, LUX 0.75) but also by soil Cd (GAN 0.36, LUX 0.61) (Fig. 5). In LUX plants, shoot $\mathrm{Zn}$ concentration was also negatively influenced by $\mathrm{N}-\mathrm{NO}_{3}$ $(-0.62)$ and GC $(-0.31)$, and positively by Sand $(0.54)$, while GAN plants were negatively influenced by $\mathrm{NH}_{4}(-0.17)$ and $\mathrm{Ca}(-0.28)$.

On the whole, $\mathrm{Cd}$ and $\mathrm{Zn}$ uptake (i.e. product of biomass and shoot $\mathrm{Cd}$ or $\mathrm{Zn}$ concentrations) were explained by a combination of the above mentioned variables, with however trade-off for variables who had opposed effects on the two components of the uptake. Cadmium uptake mostly depended on soil Cd (1.94) and Zn (-0.91), and secondarily OM (0.41), $\mathrm{Cu}(-0.32)$ and GC $(-0.31)$ for LUX, while for GAN population soil Cd (1.21), CARB (-0.51), Cu (-0.41) and OM (0.3) were the main explanatory variables (Fig. 4). Zinc uptake depended mostly on soil $\mathrm{Cd}$ (or $\mathrm{Zn})(0.91)$ and $\mathrm{OM}(0.92)$ but also $\mathrm{P}(0.5)$ and $\mathrm{Pb}$ (0.38) for LUX, and on $\mathrm{Zn}(0.71)$, OM (0.49) and $\mathrm{Cu}(-0.31)$ for GAN (Fig. 5). Effect curves of the selected variables on Cd uptake showed that soil $\mathrm{Cd}$ was by far the most influential variable and that the negative effect of soil $\mathrm{Zn}$ on LUX uptake occurred mostly between 0 and $300 \mathrm{mg}$ $\mathrm{Zn} \mathrm{kg}^{-1}$ (Fig. S2). For Zn uptake, the effect curves highlighted the larger influence of soil determinants other than soil Zn compared to Cd uptake (Fig. S3).

\subsection{Effect of nitrogen fertilization}

The $\mathrm{N}$ treatments alone did not consistently increase biomass production over all soils, but the interaction between treatment and soil factor was highly significant $(p<0.001)$ (Table $\mathrm{S} 3$ ), suggesting that $\mathrm{N}$ input had different effects on biomass depending on soil properties. To elucidate the soil $\times$ treatment interaction, we performed an analysis of covariance using both initial soil concentrations in $\mathrm{NH}_{4}^{+}$and $\mathrm{NO}_{3}^{-}$as covariables, with both populations pooled since there was no population effect on biomass production. Both $\mathrm{NH}_{4}^{+}$and $\mathrm{NO}_{3}^{-}$were significant covariables of the biomass production ( $p<0.001$ and $p<0.01$, respectively) but only $\mathrm{NO}_{3}^{-}$had a significant interaction with the treatment effect $(p<0.01)$

\section{Shoot Cd concentration}
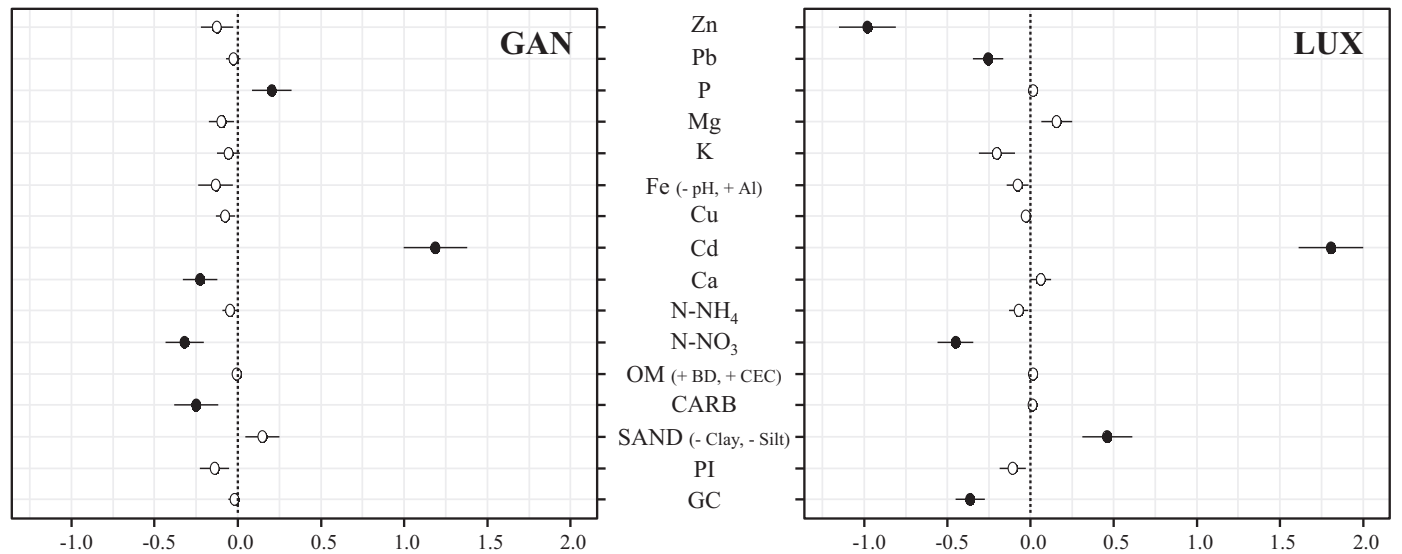

\section{Cd uptake}
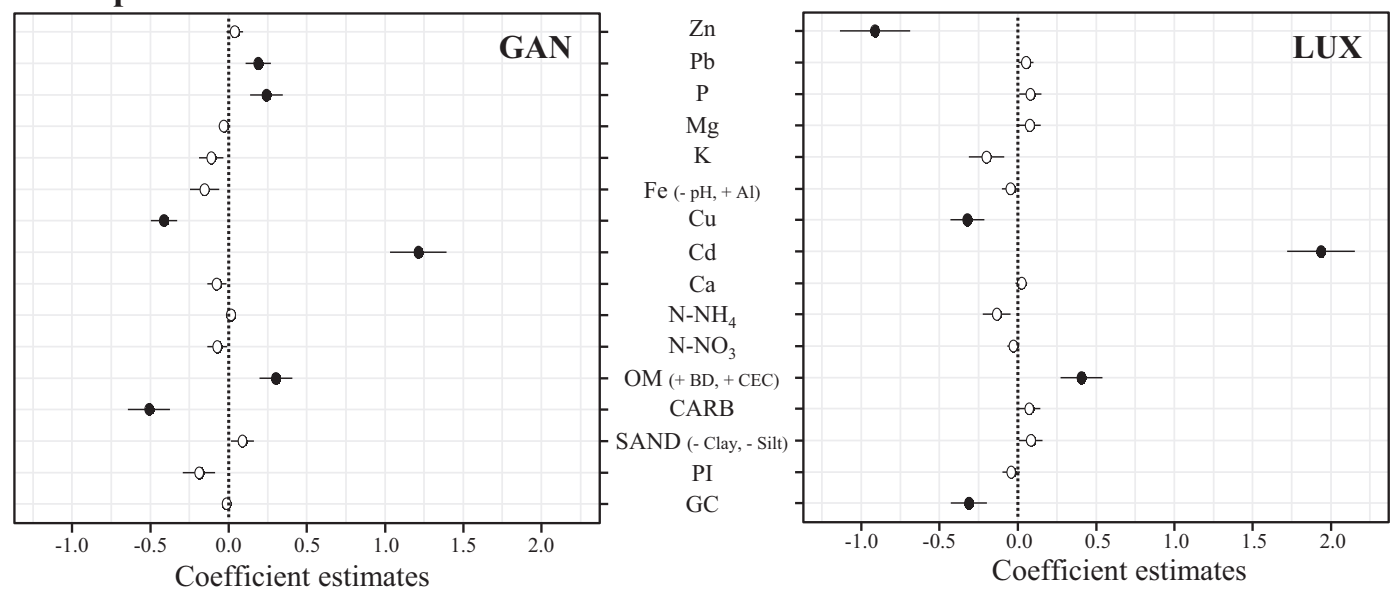

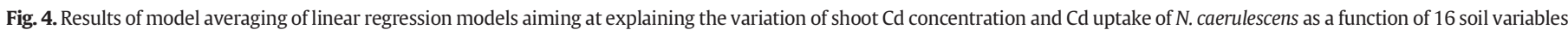

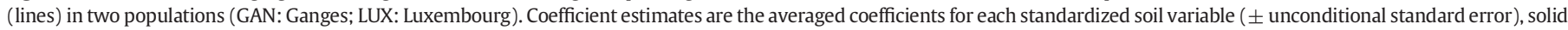

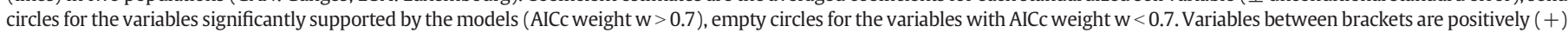
or negatively $(-)$ correlated $(|r|>0.7)$ to the variable retained in model selection. CARB $=$ Carbonate index, PI $=$ Permeability index, GC $=$ Gravel charge. 
Shoot $\mathrm{Zn}$ concentration
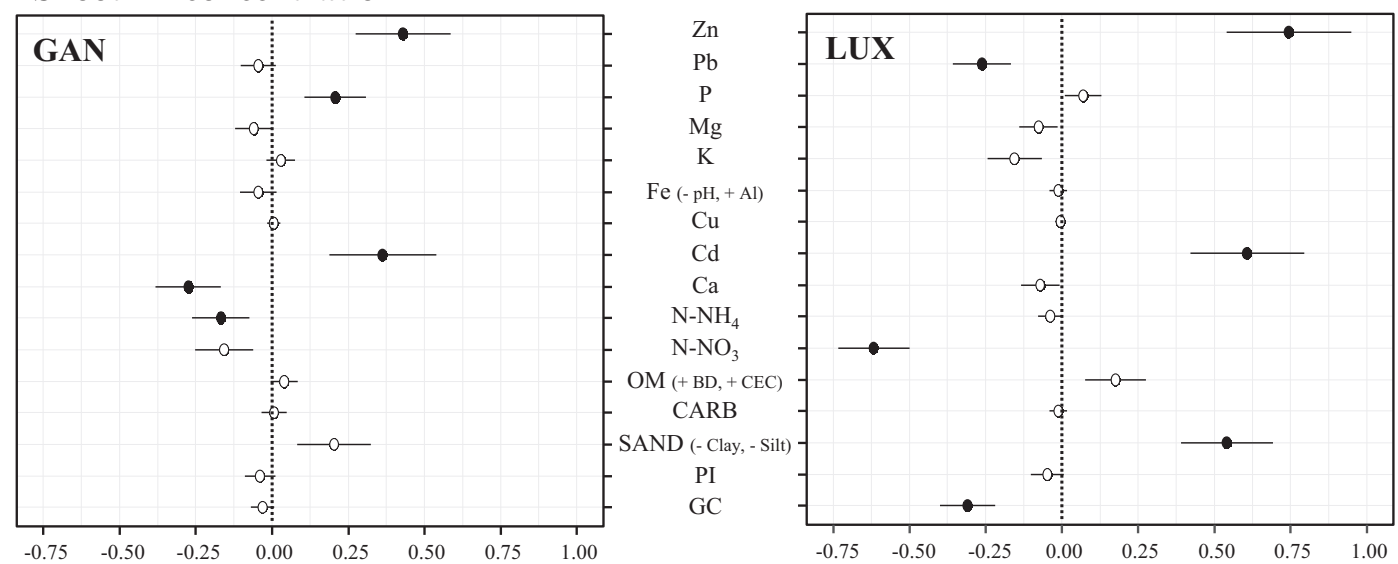

\section{Zn uptake}
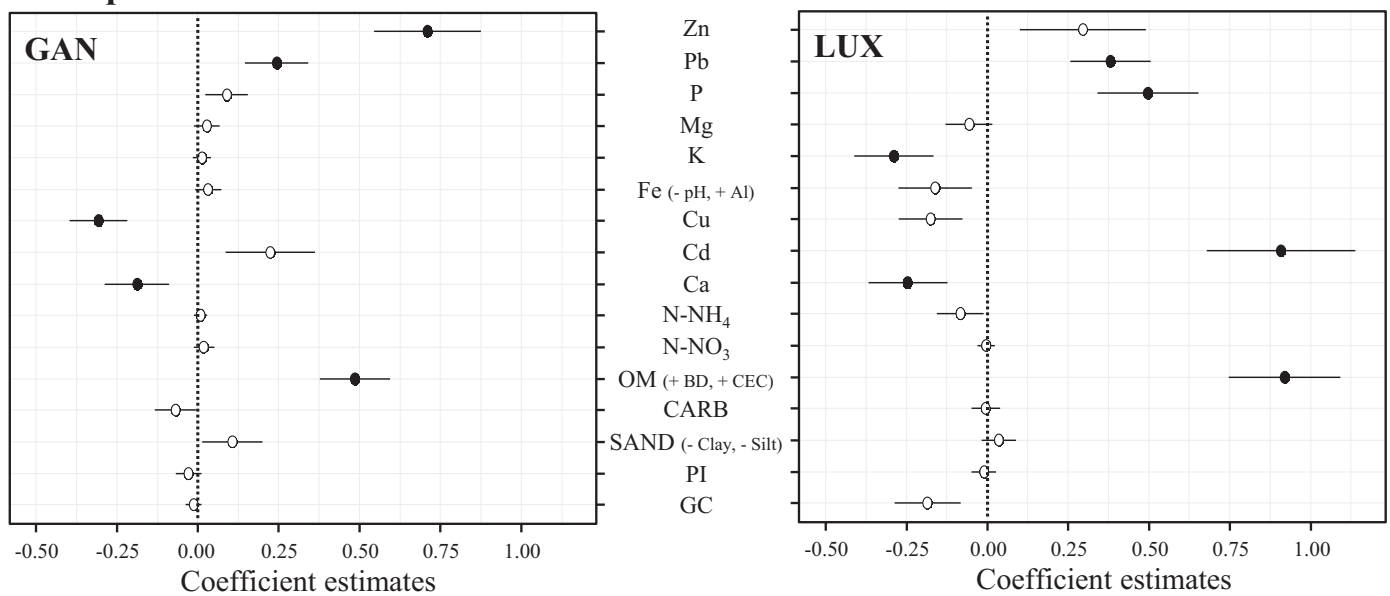

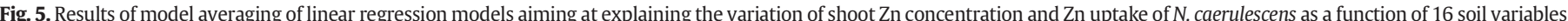

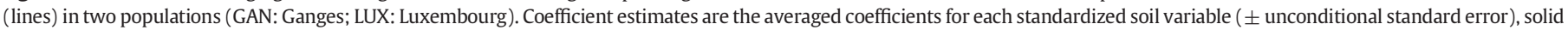

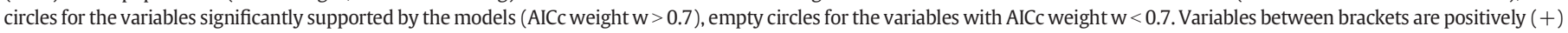
or negatively $(-)$ correlated $(|r|>0.7)$ to the variable retained in model selection. CARB $=$ Carbonate index, PI $=$ Permeability index, GC $=$ Gravel charge.

(Table S5). This indicates that there was no positive effect of the treatment (but rather a negative one) on biomass production at the highest initial soil $\mathrm{NO}_{3}^{-}$content (Fig. 6). We then performed a second analysis of variance of biomass production including only the soils with $\mathrm{N}$ content

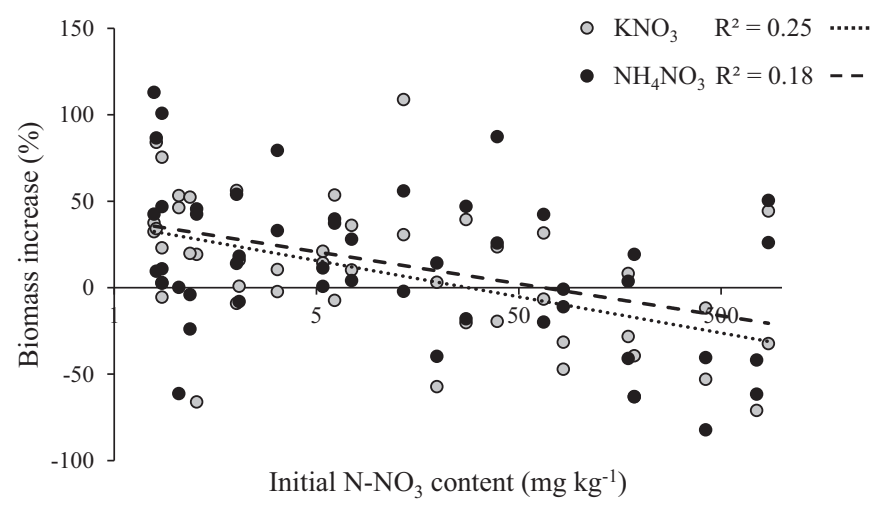

Fig. 6. Effect of two nitrogen treatments $\left(\mathrm{KNO}_{3}\right.$ and $\left.\mathrm{NH}_{4} \mathrm{NO}_{3}\right)$ on $\mathrm{N}$. caerulescens biomass (Ganges, GAN, and Luxembourg, LUX populations pooled) depending on the initial $\mathrm{N}^{-\mathrm{NO}_{3}}$ content in the 24 different soils (logarithmic scale). Treatment effect is calculated as $\left(\mathrm{MBT}-\mathrm{MB}_{\mathrm{C}}\right) / \mathrm{MB}_{\mathrm{C}}$ where $\mathrm{MB}$ is the mean biomass for one population on one soil either on one of the two treatments $\left(\mathrm{MB}_{\mathrm{T}}\right)$ or on the control $\left(\mathrm{MB}_{\mathrm{C}}\right)$. under $25 \mathrm{mg} \mathrm{N}-\mathrm{NO}_{3} \mathrm{~kg}^{-1}$ DS (17 out of 24) because it corresponds approximately to the threshold value (Fig. 6), and the treatment effect was then significant $\left(F_{2,234}=4.83, p<0.01\right.$, where $F_{x, y}$ is the $\mathrm{F}$ value of the treatment factor, $\mathrm{x}$ and $\mathrm{y}$ are the degrees of freedom of the treatment and the residuals, respectively). Considering only those soils, the average total biomass was higher on $\mathrm{NH}_{4} \mathrm{NO}_{3}$ and $\mathrm{KNO}_{3}$ treatments compared to the control, by $15 \%$ for GAN and $22 \%$ for LUX.

$\mathrm{N}$ addition significantly influenced both $\mathrm{Cd}(p<0.001)$ and $\mathrm{Zn}$ $(p<0.001)$ shoot concentrations, but differently depending on the nitrate salt. Ammonium nitrate addition had a negative effect on metal concentrations (Fig. 7). Shoot Cd concentration was higher in plants of both populations grown on the control $\left(26 \mu \mathrm{g} \mathrm{g}^{-1}\right)$ and on the $\mathrm{KNO}_{3}$ treatment $\left(24 \mu \mathrm{g} \mathrm{g}^{-1}\right)$ than on the $\mathrm{NH}_{4} \mathrm{NO}_{3}$ treatment $\left(20 \mu \mathrm{g} \mathrm{g}^{-1}\right)$ (Table S3). Shoot $\mathrm{Zn}$ concentrations for the LUX population were lower on $\mathrm{NH}_{4} \mathrm{NO}_{3}\left(4190 \mu \mathrm{g} \mathrm{g}^{-1}\right)$ and $\mathrm{KNO}_{3}\left(4260 \mu \mathrm{g} \mathrm{g}{ }^{-1}\right)$ treatment than on the control $\left(4630 \mu \mathrm{g} \mathrm{g}^{-1}\right)$ while there was no effect for GAN population (Table S3). Overall, the treatment effect on Cd uptake (product of biomass and shoot $\mathrm{Cd}$ concentration) was significant, as $\mathrm{Cd}$ uptake was about $15 \%$ lower with the $\mathrm{NH}_{4} \mathrm{NO}_{3}$ treatment compared to the control $(p<0.001)$ while there was no significant effect of the $\mathrm{KNO}_{3}$ treatment but there was however a significant interaction between soil and treatment. The treatment had no pure effect on $\mathrm{Zn}$ uptake, but once again soil $\times$ treatment interaction was significant. When considering only the 15 soils with $<25 \mathrm{mg} \mathrm{N}-\mathrm{NO}_{3} \mathrm{~kg}^{-1} \mathrm{DS}$, there was no significant treatment effect on $\mathrm{Cd}$ and $\mathrm{Zn}$ uptake which 

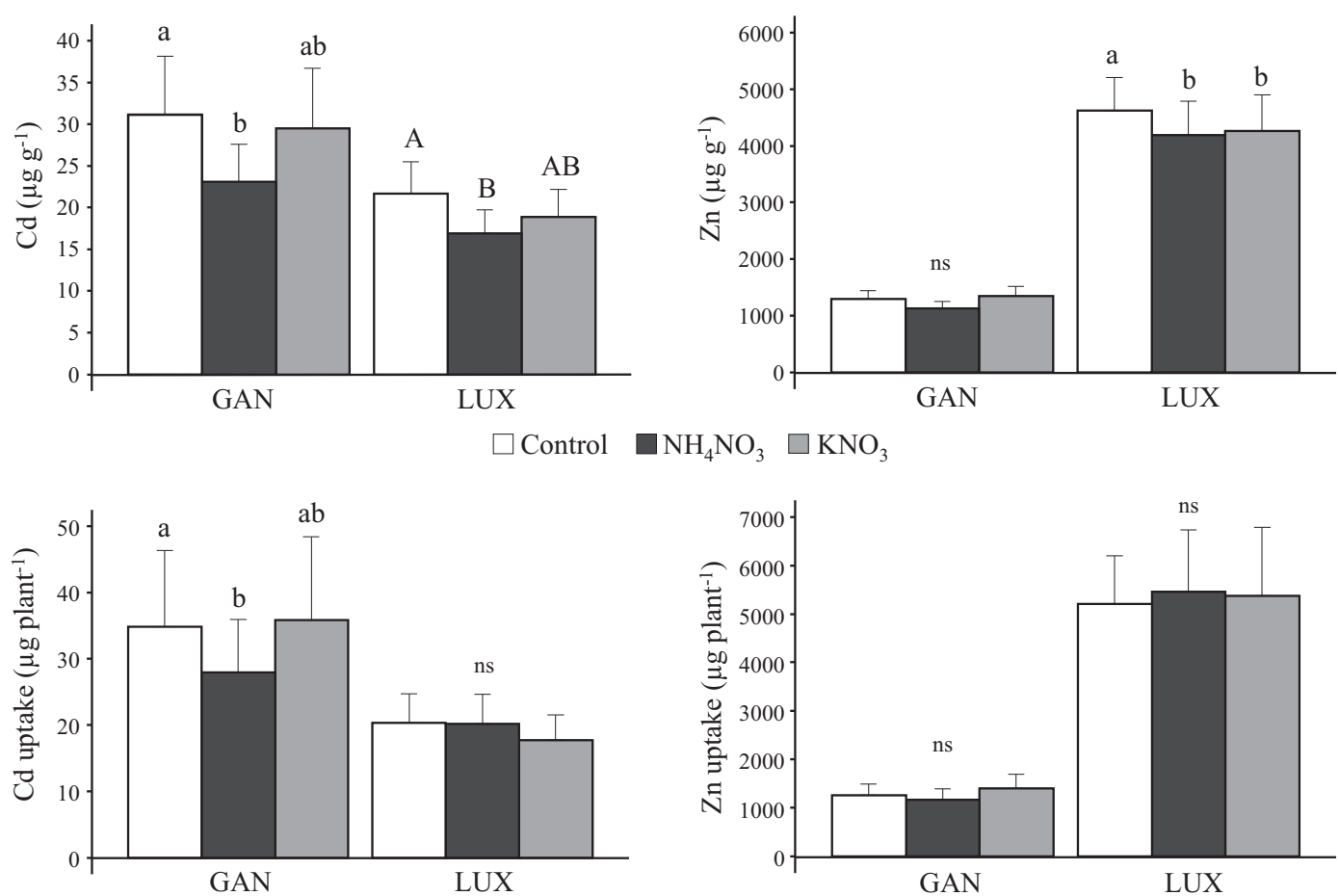

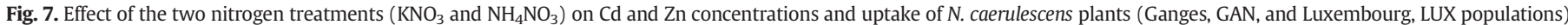
across 24 soils. Data are means + standard errors $(n=68-80$ plants). Different letters indicate significant differences among nitrogen treatments for each population separately.

shows that the biomass gain was offset by reduced shoot $\mathrm{Cd}$ and $\mathrm{Zn}$ concentrations.

\subsection{Metal removal}

Average metal uptake was calculated as the proportion of the metal mass initially present in the pot that was harvested in the aboveground biomass (metal mass in the plant/metal mass in the soil). Mean Cd uptake across all soils and treatments is about $5 \%$ of the exchangeable Cd content (ranging from 2 to $10 \%$ ) and $3 \%$ of the total $\mathrm{Cd}$ content (ranging from $0.3 \%$ to $6 \%$ ) with GAN population (Fig. 8). Cadmium uptake with LUX population is not significantly different from GAN except on highly contaminated soils, where it is smaller. On the contrary, LUX population yielded a higher Zn uptake, on average $6 \%$ of the exchangeable content (ranging from 1 to $14 \%$ ) and $2 \%$ of the total content (ranging from $0.3 \%$ to $4.4 \%$ ) compared to $2 \%$ of the exchangeable content (ranging from 0.2 to $4 \%$ ) and $0.6 \%$ of the total content (ranging from $0.1 \%$ to $1.6 \%$ ) with GAN population (Fig. 8). Cd extraction efficiency with GAN increases with soil contamination, being maximal for total concentrations between 2 and $10 \mathrm{mg}$ $\mathrm{Cd} \mathrm{kg}^{-1}$ (7.6\% and 5.5\% of exchangeable and total content), while on the only soil with higher contamination (LIE $20 \mathrm{mg} \mathrm{Cd} \mathrm{kg}^{-1}$ ) the extraction rate was much lower ( 2 and $1.4 \%$ ). Zn extraction with LUX is also more efficient at intermediate contamination level (300 and $1000 \mathrm{mg} \mathrm{Zn} \mathrm{kg}^{-1}$ ) than at low (<300 $\mathrm{mg} \mathrm{Zn} \mathrm{kg}^{-1}$ ) or very high (1000 $\mathrm{mg} \mathrm{Zn} \mathrm{kg}^{-1}$ ) levels of contamination.
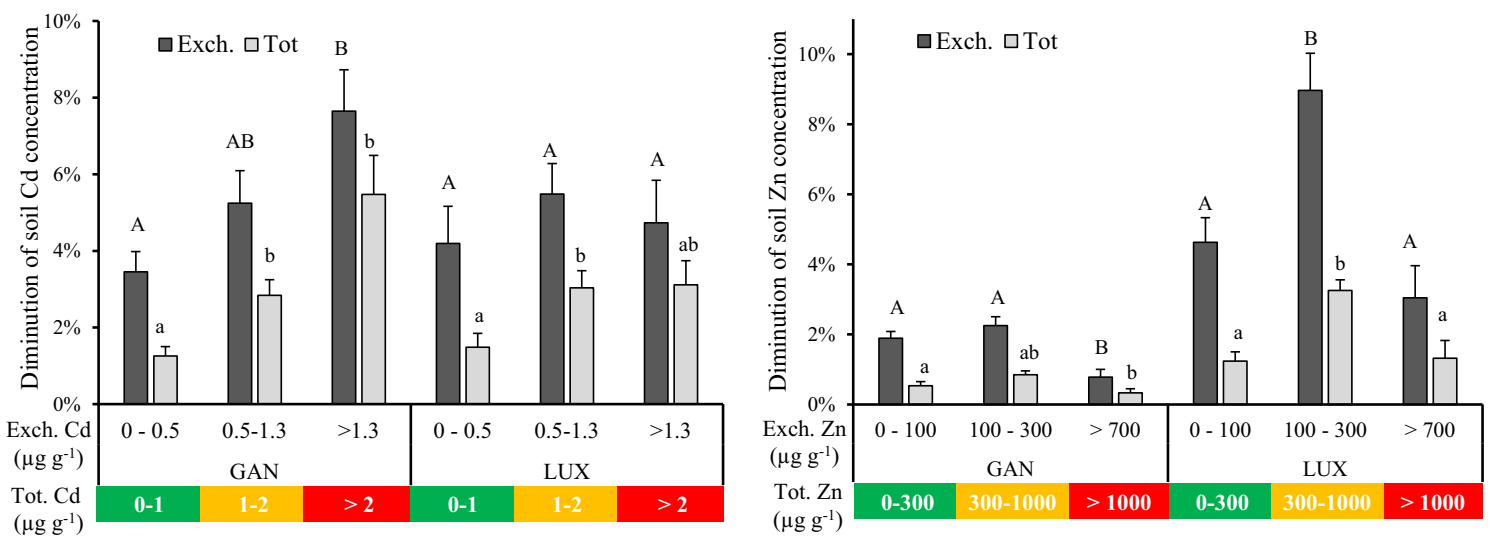

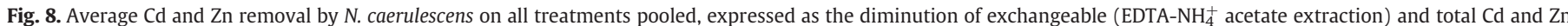

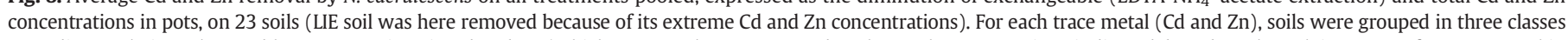

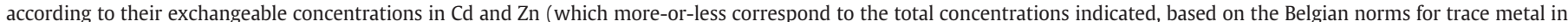

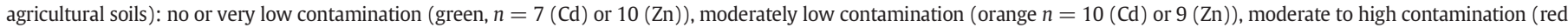

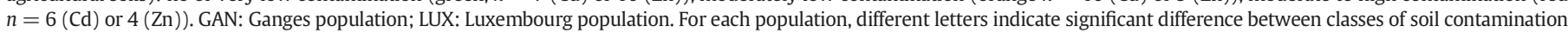
at the $p<0.05$ level ( $t$-tests with Šidák correction). (For interpretation of the references to colour in this figure legend, the reader is referred to the web version of this article.) 


\section{Discussion}

In this study we have compared for the first time two contrasting populations of $N$. caerulescens on a wide range of moderately contaminated soils to assess the influence of natural soil variation on phytoextraction efficiency. We also investigated the effect of a common agricultural practice, $\mathrm{N}$ fertilization, on phytoextraction. The originality of this work was to study the effect of $>16$ soil variables on both biomass and metal concentrations - the former often being neglected when considering extraction efficiency - with a realistic growth length ( 20 weeks).

\subsection{Influence of soil factors on biomass production}

Plant biomass production varied by more than tenfold among soils, which indicates a strong influence of soil properties. Sterckeman and Puschenreiter (2018) pointed out that Cd phytoextraction efficiency varies by a factor of 70 between sites.

Interestingly, GAN and LUX populations showed similar growth responses to soil variables. First, $N$. caerulescens growth was clearly stimulated by higher organic matter (OM) content and lower bulk density (BD). This positive influence could be interpreted by the benefits of soil OM on chemical and physical properties: higher fertility and a greater soil macroporosity. Nevertheless, since none of the major cations $(\mathrm{K}, \mathrm{P}$, and $\mathrm{Mg})$ and $\mathrm{N}$ forms are correlated with $\mathrm{OM}(r<0.5$, Table S6), the effect on chemical fertility seems less important. This rather supports the field observation of a high sensitivity of the species to soil compaction, and that natural populations mostly grow on shallow and coarse substrates (Basic et al., 2006; Molitor et al., 2005; Sirguey et al., 2018). Our results suggest that $N$. caerulescens grows best in soils with $\mathrm{OM}>7 \%$ and soil bulk density $<1.05 \mathrm{~kg} / \mathrm{dm}^{3}$. In a pot experiment on 7 soils, Knight et al. (1997) obtained data showing a positive correlation between soil organic carbon and $N$. caerulescens biomass production ( $r=0.9$ using Tables 1 and 2 data from Knight et al., 1997). In a field trial on 10 soils, Maxted et al. (2007) found no significant correlation between $\mathrm{OM}$ and biomass but the best yield was still obtained on a soil with high OM content (22\%) while the lowest was on a clayey soil with lower OM (5-10\%). In this context, the negative influence of sand content (varying from 30 to $80 \%$ ) in the same model (and hence positive of clay and silt) on growth may seem counterintuitive, but it could be interpreted as a positive effect of increasing clay and silt content for water retention in these relatively sandy soils. Noccaea caerulescens could have a preference for soils with good drainage but with a minimum water retention capacity to prevent excessive drying.

Another variable that positively influences biomass is $\mathrm{N}$ as available nitrate $\left(\mathrm{N}_{-} \mathrm{NO}_{3}\right)$. The dominant $\mathrm{N}$ form in most soils was $\mathrm{NO}_{3}^{-}$which could explain why $\mathrm{NO}_{3}^{-}$rather than $\mathrm{NH}_{4}^{+}$was selected as a predictor of biomass production. We here confirm the positive impact of increasing $\mathrm{N}$ on $\mathrm{N}$. caerulescens growth on a large range of field soil concentrations in $\mathrm{N}^{-\mathrm{NO}_{3}}$ (from 1 to $858 \mathrm{mg} \mathrm{kg}{ }^{-1} \mathrm{DS}$, median $7 \mathrm{mg} \mathrm{kg}{ }^{-1} \mathrm{DS}$ ) which had already been demonstrated earlier with synthetic fertilizers (Schwartz et al., 2003; Xie et al., 2009).

Our models also highlighted that two trace metals, $\mathrm{Cu}$ and $\mathrm{Pb}$, influence biomass production, positively for $\mathrm{Pb}$ and negatively for $\mathrm{Cu}$. $\mathrm{Cu}$ concentrations in the four most contaminated soil range from 140 and $240 \mathrm{mg} \mathrm{kg}^{-1}$, and appear to inhibit N. caerulescens growth. Such growth inhibition had already been demonstrated in previous works but at higher concentrations (1200 $\mathrm{mg} \mathrm{kg}^{-1}$ ) (Lombi et al., 2001b; Walker and Bernal, 2004). The positive influence of $\mathrm{Pb}$ on both populations is more unexpected and less straightforward to explain. Growth stimulation of $N$. caerulescens by trace metals has already been shown for Cd and Zn (Escarré et al., 2000; Pongrac et al., 2009) - the two hyperaccumulated trace metals - but never in the case of $\mathrm{Pb}$. We know that $N$. caerulescens can grow on sites with very high Pb contamination (frequently between 10,000 and $20,000 \mathrm{mg} \mathrm{kg}^{-1}$; Escarré et al., 2011) and therefore it makes sense that no negative effect of $\mathrm{Pb}$ is found here. A potential covariation with other trace metals $(\mathrm{Cd}, \mathrm{Cu}$ and $\mathrm{Zn})$ or $\mathrm{OM}$ can be ruled out since $\mathrm{Pb}$ is not strongly correlated $(r<0.5)$ to any other soil variable. Furthermore, models without $\mathrm{Pb}$ explain less variation in biomass and had a higher AICc value. The most convincing explanation would be a direct effect of $\mathrm{Pb}$ on soil pathogens and pests, which could therefore lead to an indirect effect on plant growth by decreasing the negative impact of plant root feeders and pathogens. The main pest and pathogens of $N$. caerulescens previously identified are sciarid flies larvae (in controlled conditions, personal observation), and fungal diseases causing damping off and root rot (Phytophthora sp., Fusarium sp. or Pythium sp.) (Maxted et al., 2007; Simmons et al., 2015). The inhibition of soil pathogen development by elevated soil $\mathrm{Pb}$ content has already been demonstrated (Harris and Birch, 1988; Ngu et al., 1998). This hypothesis is also supported by the significant correlation between survival rate and soil $\mathrm{Pb}$ concentration (binomial generalized linear model, $p<0.05$, Table S7).

It has to be underlined that soil Fe and $\mathrm{pH}$ (highly correlated: $r=$ -0.83 ) did not significantly influence $N$. caerulescens growth in the models in the $\mathrm{pH}$ range of urban soils used in this study (6.2-8), which is narrower than previous studies (Maxted et al., 2007; Wang et al., 2006; Yanai et al., 2006) that highlighted a significant effect of $\mathrm{pH}$ on growth (from $\mathrm{pH} 4.4$ to 7.8 ). Finally, none of the soil major cations ( $\mathrm{Ca}, \mathrm{K}, \mathrm{Mg}$ and $\mathrm{P}$ ) were selected to explain the variation in biomass production.

The two populations used in this study had similar total biomass production, but had a very different ratio of reproductive/vegetative biomass (R/V): GAN having a higher proportion of reproductive parts $(\mathrm{R} / \mathrm{V}$ 0.54) than LUX (R/V 0.13). This is explained by the difference in dominant life cycles (annual for GAN, biennial for LUX), already shown in phytoextraction field trials (Jacobs et al., 2018b).

\subsection{Soil influence on metal uptake}

Accumulation levels were low compared to what is obtained in field trials on some of the same soils of origin (2 to 10 times less) (Jacobs et al., 2017, 2018a, b) but it can be explained by a shorter growth and a smaller soil volume in this pot experiment. The two populations showed the expected contrasting patterns of shoot $\mathrm{Cd}$ and $\mathrm{Zn}$ concentrations (Escarré et al., 2000; Jacobs et al., 2017; Meerts and van Isacker, 1997): higher shoot $\mathrm{Zn}$ in LUX plants and higher shoot $\mathrm{Cd}$ in GAN plants. The difference in Cd concentrations between populations was however not present on all soils and was less pronounced than expected considering the high potential for $\mathrm{Cd}$ accumulation of GAN ( $31 \mu \mathrm{g} \mathrm{g}^{-1}$ in GAN vs $22 \mu \mathrm{g} \mathrm{g}^{-1}$ in LUX). Soil factors limiting Cd bioavailability could be an explanation.

Exchangeable soil $\mathrm{Cd}$ and $\mathrm{Zn}$ were the main explanatory variables of $\mathrm{Cd}$ and $\mathrm{Zn}$ concentrations, respectively, in aboveground parts of $N$. caerulescens, as already highlighted in numerous studies (McGrath et al., 2006; Maxted et al., 2007; Yanai et al., 2006). This was expected considering the large variation of soil contamination in pots (0.2-14 $\mathrm{mg} \mathrm{Cd} \mathrm{kg}^{-1}$ and $30-3200 \mathrm{mg} \mathrm{Zn} \mathrm{kg}{ }^{-1}$ as exchangeable forms). However, other soil variables also influenced shoot metal concentrations. We confirm the negative effect of available $\mathrm{NO}_{3}^{-}$(or $\mathrm{NH}_{4}^{+}$ for $\mathrm{Zn}$ concentrations in GAN) on shoot concentrations of $\mathrm{Cd}$ and $\mathrm{Zn}$ in both populations shown by previous studies (Monsant et al., 2008; Xie et al., 2009; Jacobs et al., 2018a). This effect can be linked to a dilution of metals absorbed in larger plants $\left(\mathrm{NO}_{3}^{-}\right.$has a positive influence on shoot growth) but it could also be due to an increased shoot-root ratio (Roosens et al., 2003) in the presence of high $\mathrm{N}$ concentrations and hence to a reduced soil exploration by roots (Morris et al., 2017).

There was a negative effect of soil $\mathrm{Zn}$ and $\mathrm{Pb}$ on shoot $\mathrm{Cd}$ concentrations in LUX population but not in GAN. This is coherent with the difference in Cd accumulation mechanisms between ecotypes, GAN ecotype having higher gene copy number and level of expression of specific cadmium transporters (HMA4 and HMA3) than other MET or NMET populations (Craciun et al., 2012; Halimaa et al., 2014; 
Lombi et al., 2001a; Roosens et al., 2003). Cd uptake by NMET is therefore more sensitive to competition with $\mathrm{Zn}$.

Increasing gravel charge of soils had a negative impact on shoot $\mathrm{Cd}$ and $\mathrm{Zn}$ concentrations and uptake in LUX plants, which can easily be interpreted as a dilution of available metal mass in the pot when the gravel charge is high. The negative effect of the carbonate index (CARB, separating soils below and above $\mathrm{pH} 7$ ) on Cd concentrations and uptake with GAN population can be linked to a lower $\mathrm{Cd}$ bioavailability with the higher carbonate content. This highlights that soil $\mathrm{pH} 7$ is the threshold determining Cd bioavailability for $N$. caerulescens in these soils, as Maxted et al. (2007) also observed, and also explains why GAN did not accumulate more Cd than LUX on seven soils with $\mathrm{pH}>7$ (AN3, AN4, BEM, MAS, NAV, SOL6, WIE). Finally the slightly negative effect of $\mathrm{Ca}$ on $\mathrm{Cd}$ concentrations and uptake suggests a competition for uptake between $\mathrm{Ca}$ and $\mathrm{Cd}$ as already observed in the Prayon population, which has however a very different genetic background than GAN (Dechamps et al., 2005; Roosens et al., 2003; Zhao et al., 2002). Rees et al. (2015) suggested that the lower bioavailability of Ca induced by the addition of biochar could explain the simultaneous increase in $\mathrm{Cd}$ and $\mathrm{Zn}$ uptake by the population of Ganges.

\subsection{Effect of nitrogen fertilization on biomass, concentrations and uptake}

We tested the effect of adding environmentally sustainable inputs of two $\mathrm{N}$ fertilizers ( $40 \mathrm{mg} \mathrm{N} \mathrm{kg}{ }^{-1}$ as $\mathrm{KNO}_{3}$ or $\mathrm{NH}_{4} \mathrm{NO}_{3}$ ) because it is among the easiest ways to improve soil chemical fertility and enhance shoot biomass. Previously, two tests of sustainable $\mathrm{N}$ fertilization with $\mathrm{NH}_{4} \mathrm{NO}_{3}$ (about $100 \mathrm{~kg} \mathrm{~N} \mathrm{ha}^{-1}$ or $30 \mathrm{mg} \mathrm{N} \mathrm{kg}^{-1}$ ) on $N$. caerulescens yielded highly variable biomass gains $(+15-80 \%)$ depending on the soil (Sirguey et al., 2006, Jacobs et al., 2018a). Other studies also suggest that there might be some preference of $\mathrm{N}$. caerulescens for $\mathrm{NO}_{3}^{-}$rather than $\mathrm{NH}_{4}^{+}$(Monsant et al., 2008; Schwartz et al., 2003; Xie et al., 2009). We therefore compared two sources of $\mathrm{N}$.

Nitrogen fertilization had a positive impact on $N$. caerulescens biomass production only in soils with low initial $\mathrm{N}$ content $\left(<25 \mathrm{mg} \mathrm{N}-\mathrm{NO}_{3} \mathrm{~kg}^{-1}\right.$ ) but the growth stimulation for these soils was rather limited ( +15 and $23 \%$ on average for GAN and LUX populations, respectively). The two $\mathrm{N}$ fertilizers $\left(\mathrm{KNO}_{3}\right.$ or $\left.\mathrm{NH}_{4} \mathrm{NO}_{3}\right)$ gave the same biomass increase. On soils with high initial $\mathrm{N}$ content $\left(>100 \mathrm{mg} \mathrm{N} \mathrm{kg}^{-1}\right.$ ), $\mathrm{N}$ addition had a negative effect on biomass. We could speculate that $\mathrm{N}$ fertilization enhance fungal development as already observed in the field (Jacobs et al., 2018a), and supported by the slightly lower survival rate on the $\mathrm{N}$ treatments (82.5\%) compared to the control (89\%) ( $\chi^{2}$ test, $\left.p<0.05\right)$. This would explain why beyond a certain threshold of initial $\mathrm{N}$ in the soil, the negative impact of adding synthetic fertilizers on plant disease is stronger than growth stimulation. Furthermore, the negative effect of $\mathrm{NH}_{4} \mathrm{NO}_{3}$ on $\mathrm{Cd}$ and $\mathrm{Zn}$ concentrations offset the small biomass gain obtained with fertilization, which is coherent with the results of Sirguey et al. (2006) with similar levels of fertilization. Overall, $\mathrm{N}$ fertilization had a neutral effect on the wide range of garden and wasteland soils used in this study. It can be concluded that $\mathrm{N}$ fertilization does not improve phytoextraction except on soils with very low $\mathrm{N}$ content.

\section{Conclusion}

This study shows that soil exchangeable Cd and $\mathrm{Zn}$ are the major soil drivers of $\mathrm{Cd}$ and $\mathrm{Zn}$ uptake by $\mathrm{N}$. caerulescens. Beyond soil $\mathrm{Cd}$ and $\mathrm{Zn}$ concentrations, the secondary drivers of trace metal uptake are organic matter content and bulk density which stimulate plant growth (for a high OM content and low bulk density), and soil Cu exchangeable concentrations which influence biomass production negatively. This confirms the low tolerance of $N$. caerulescens to $\mathrm{Cu}$ at even lower $\mathrm{Cu}$ concentrations (100-240 $\mathrm{mg} \mathrm{kg}^{-1}$ ) than previously demonstrated. The negative effect of high soil Zn content on Cd uptake in NMET population (LUX), but not in GAN, is also highlighted on field contaminated soils, while Cd uptake by GAN is negatively impacted by the carbonate content of the soil. Finally, we show that $\mathrm{N}$ fertilization at environmentally acceptable doses is not an efficient way of improving phytoextraction efficiency. This stresses the need to characterize extensively soil determinants for a better predictability of phytoextraction, as excessive $\mathrm{Cu}$ exchangeable concentrations, low OM content or high carbonate content can clearly impact negatively the extraction efficiency. Our study shows that extraction efficiency is best for moderate soil contamination in $\mathrm{Cd}\left(2-10 \mathrm{mg} \mathrm{kg}^{-1}\right)$ and $\mathrm{Zn}\left(300-1000 \mathrm{mg} \mathrm{kg}^{-1}\right)$.

\section{Acknowledgments}

Arnaud Jacobs is a research fellow of the Fonds pour la formation à la Recherche dans l'Industrie et dans l'Agriculture (FRIA, Belgium). We are grateful to Kristel Wart, Luc Dekelver, Sophie Lorent and Dirfy-Eleni Giatzouzaki for their technical help during the experiment, and to David Bauman for his advice on statistical analysis. We thank three anonymous reviewers for their constructive comments on the manuscript.

\section{Appendix A. Supplementary data}

Supplementary data to this article can be found online at https://doi. org/10.1016/j.scitotenv.2019.02.073.

\section{References}

Alloway, B.J. (Ed.), 2012. Heavy Metals in Soils: Trace Metals and Metalloids in Soils and Their Bioavailability. Environmental Pollution. Springer, Netherlands.

Assunção, A.G., Schat, H., Aarts, M.G., 2003. Thlaspi caerulescens, an attractive model species to study heavy metal hyperaccumulation in plants. New Phytol. 159, 351-360.

Basic, N., Keller, C., Fontanillas, P., Vittoz, P., Besnard, G., Galland, N., 2006. Cadmium hyperaccumulation and reproductive traits in natural Thlaspi caerulescens populations. Plant Biol. 8, 64-72.

Bennett, F.A., Tyler, E.K., Brooks, R.R., Gregg, P.E.H., Stewart, R.B., 1998. Fertilisation of hyperaccumulators to enhance their potential for phytoremediation and phytomining. In: Brooks, R.R. (Ed.), Plants That Hyperaccumulate Heavy Metals. $\mathrm{CAB}$ International, Wallingford.

Burnham, K.P., Anderson, D.R., 2002. Model Selection and Multimodel Inference. Springer Calcagno, V., de Mazancourt, C., 2010. glmulti: an R package for easy automated model selection with (generalized) linear models. J. Stat. Softw. 34, 1-29.

Cottenie, A., Camerlynck, R., Verloo, M., Dhaese, A., 1979. Fractionation and determination of trace elements in plants, soils and sediments. Pure Appl. Chem. 52, 43-53.

Craciun, A.R., Meyer, C.L., Chen, J., Roosens, N., De Groodt, R., Hilson, P., et al., 2012. Variation in HMA4 gene copy number and expression among Noccaea caerulescens populations presenting different levels of Cd tolerance and accumulation. J. Exp. Bot. 63, 4179-4189.

Dechamps, C., Roosens, N.H., Hotte, C., Meerts, P., 2005. Growth and mineral element composition in two ecotypes of Thlaspi caerulescens on Cd contaminated soil. Plant Soil 273, 327-335.

Dechamps, C., Noret, N., Mozek, R., Escarré, J., Lefèbvre, C., Gruber, W., et al., 2008. Cost of adaptation to a metalliferous environment for Thlaspi caerulescens: a field reciprocal transplantation approach. New Phytol. 177, 167-177.

Escarré, J., Lefèbvre, C., Gruber, W., Leblanc, M., Lepart, J., Rivière, Y., et al., 2000. Zinc and cadmium hyperaccumulation by Thlaspi caerulescens from metalliferous and nonmetalliferous sites in the Mediterranean area: implications for phytoremediation. New Phytol. 145, 429-437.

Escarré, J., Lefèbvre, C., Raboyeau, S., Dossantos, A., Gruber, W., Cleyet Marel, J.C., et al., 2011. Heavy metal concentration survey in soils and plants of the Les Malines mining district (Southern France): implications for soil restoration. Water Air Soil Poll. 216, 485-504

Fox, J., Weisberg, S., Bates, D., et al., 2011. Package ‘car'. http://cran.rproject.org/web/packages/car/car.pdf.

Halimaa, P., Lin, Y.F., Ahonen, V.H., Blande, D., Clemens, S., Gyenesei, A., et al., 2014. Gene expression differences between Noccaea caerulescens ecotypes help to identify candidate genes for metal phytoremediation. Environ. Sci. Technol. 48, 3344-3353.

Hammer, D., Keller, C., 2003. Phytoextraction of Cd and $\mathrm{Zn}$ with Thlaspi caerulescens in field trials. Soil Use Manag. 19, 144-149.

Harris, J.A., Birch, P., 1988. The effect of zeolite on the toxicity of lead to fungi. Environ. Pollut. 49, 235-241.

Hutchinson, J.J., Young, S.D., McGrath, S.P., West, H.M., Black, C.R., Baker, A.J.M., 2000. Determining uptake of 'non-labile' soil cadmium by Thlaspi caerulescens using isotopic dilution techniques. New Phytol. 146, 453-460.

Jacobs, A., Drouet, T., Sterckeman, T., Noret, N., 2017. Phytoremediation of urban soils contaminated with trace metals using Noccaea caerulescens: comparing nonmetallicolous populations to the metallicolous 'Ganges' in field trials. Environ. Sci. Pollut. Res. 24, 8176-8188.

Jacobs, A., De Brabandere, L., Drouet, T., Sterckeman, T., Noret, N., 2018a. Phytoextraction of cd and Zn with Noccaea caerulescens for urban soil remediation: influence of nitrogen fertilization and planting density. Ecol. Eng. 116, 178-187. 
Jacobs, A., Drouet, T., Noret, N., 2018b. Field evaluation of cultural cycles for improved cadmium and zinc phytoextraction with Noccaea caerulescens. Plant Soil 430, 381-394.

Joimel, S., Cortet, J., Jolivet, C.C., Sabyd, N.P.A., Chenot, E.D., Branchue, P., Consalès, J.N. Lefort, C., Morel, J.L., Schwartz, C., 2016. Physico-chemical characteristics of topsoil for contrasted forest, agricultural, urban and industrial land uses in France. Sci. Total Environ. 545-546, 40-47.

Keller, C., Hammer, D., 2004. Metal availability and soil toxicity after repeated croppings of Thlaspi caerulescens in metal contaminated soils. Environ. Pollut 131, 243-254.

Knight, B., Zhao, F.J., McGrath, S.P., Shen, Z.G., 1997. Zinc and cadmium uptake by the hyperaccumulator Thlaspi caerulescens in contaminated soils and its effects on the concentration and chemical speciation of metals in soil solution. Plant Soil 197, $71-78$.

Krämer, U., 2010. Metal hyperaccumulation in plants. Annu. Rev. Plant Biol. 61, 517-534.

Legendre, P., Legendre, L., 2012. Numerical Ecology. Third English edition. Elsevier (990 pp.)

Lombi, E., Zhao, F.J., McGrath, S.P., Young, S.D., Sacchi, G.A., 2001a. Physiological evidence for a high-affinity cadmium transporter highly expressed in a Thlaspi caerulescens ecotype. New Phytol. 149, 53-60.

Lombi, E., Zhao, F.J., Dunham, S.J., McGrath, S.P., 2001b. Phytoremediation of heavy metalcontaminated soils. J. Environ. Qual. 30, 1919-1926.

Lombi, E., Tearall, K.L., Howarth, J.R., Zhao, F.J., Hawkesford, M.J., McGrath, S.P., 2002. Influence of iron status on cadmium and zinc uptake by different ecotypes of the hyperaccumulator Thlaspi caerulescens. Plant Physiol. 128, 1359-1367.

Maxted, A.P., Black, C.R., West, H.M., Crout, N.M.J., McGrath, S.P., Young, S.D., 2007. Phytoextraction of cadmium and zinc from arable soils amended with sewage sludge using Thlaspi caerulescens: development of a predictive model. Environ. Pollut. 150, 363-372.

McGrath, S.P., Zhao, F.J., Lombi, E., 2001. Plant and rhizosphere processes involved in phytoremediation of metal-contaminated soils. Plant Soil 232, 207-214.

McGrath, S.P., Lombi, E., Gray, C.W., Caille, N., Dunham, S.J., Zhao, F.J., 2006. Field evaluation of $\mathrm{Cd}$ and $\mathrm{Zn}$ phytoextraction potential by the hyperaccumulators Thlasp caerulescens and Arabidopsis halleri. Environ. Pollut. 141, 115-125.

Meerts, P., Grommesch, C., 2001. Soil seed banks in a heavy-metal polluted grassland at Prayon (Belgium). Plant Ecol. 155, 35-45.

Meerts, P., van Isacker, N., 1997. Heavy metal tolerance and accumulation in metallicolous and nonmetalicolous populations of Thlaspi caerulescens from continental Europe Plant Ecol. 133, 221-231.

Molitor, M., Dechamps, C., Gruber, W., Meerts, P., 2005. Thlaspi caerulescens on nonmetalliferous soil in Luxembourg: ecological niche and genetic variation in mineral element composition. New Phytol. 165, 503-512.

Monsant, A.C., Tang, C., Baker, A.J.M., 2008. The effect of nitrogen form on rhizosphere soil $\mathrm{pH}$ and zinc phytoextraction by Thlaspi caerulescens. Chemosphere 73, 635-642.

Morris, E.C., Griffiths, M., Golebiowska, A., Mairhofer, S., Burr-Hersey, J., Goh, T., et al., 2017. Shaping 3D root system architecture. Curr. Biol. 27, 919-930.

Naimi, B., Hamm, N.A.S., Groen, T.A., Skidmore, A.K., Toxopeus, A.G., 2014. Where is positional uncertainty a problem for species distribution modelling? Ecography 37, 191-203.

Ngu, M., Moya, E., Magan, N., 1998. Tolerance and uptake of cadmium, arsenic and lead by Fusarium pathogens of cereals. Int. Biodeterior. Biodegrad. 42, 55-62.

Pansu, M., Gautheyrou, J., 2006. Handbook of Soil Analysis - Mineralogical, Organic and Inorganic Methods. Springer-Verlag, Berlin Heidelberg.

Pongrac, P., Zhao, F.J., Razinger, J., Zrimec, A., Regvar, M., 2009. Physiological responses to $\mathrm{Cd}$ and $\mathrm{Zn}$ in two $\mathrm{Cd} / \mathrm{Zn}$ hyperaccumulating Thlaspi species. Environ. Exp. Bot. 66, 479-486.

R Development Core Team, 2018. R: A Language and Environment for Statistical Computing. R Foundation for Statistical Computing, Vienna, Austria.
Rees, F., Germain, C., Sterckeman, T., Morel, J.L., 2015. Plant growth and metal uptake by a non-hyperaccumulating species (Lolium perenne) and a Cd-Zn hyperaccumulator (Noccaea caerulescens) in contaminated soils amended with biochar. Plant Soil 395, $57-73$.

Roosens, N., Verbruggen, N., Meerts, P., Ximénez-Embún, P., Smith, J.A.C., 2003. Natural variation in cadmium tolerance and its relationship to metal hyperaccumulation for seven populations of Thlaspi caerulescens from western Europe. Plant Cell Environ. 26, 1657-1672.

Rosenfeld, C.E., Chaney, R.L., Martínez, C.E., 2018. Soil geochemical factors regulate Cd accumulation by metal hyperaccumulating Noccaea caerulescens (J. Presl \& C. Presl) FK Mey in field-contaminated soils. Sci. Total Environ. 616, 279-287.

Schwartz, C., Echevarria, G., Morel, J.-L., 2003. Phytoextraction of cadmium with Thlaspi caerulescens. Plant Soil 249, 27-35.

Shen, Z.G., Zhao, F.J., McGrath, S.P., 1997. Uptake and transport of zinc in the hyperaccumulator Thlaspi caerulescens and the non-hyperaccumulator Thlaspi ochroleucum. Plant Cell Environ. 20, 898-906.

Simmons, R.W., Chaney, R.L., Angle, J.S., Kruatrachue, M., Klinphoklap, S., Reeves, R.D., et al., 2015. Towards practical cadmium phytoextraction with Noccaea caerulescens. Int. J. Phytoremediation 17, 191-199.

Simon-Delso, N., San Martin, G., Bruneau, E., Delcourt, C., Hautier, L., 2017. The challenges of predicting pesticide exposure of honey bees at landscape level. Sci. Rep. 7, 3801.

Sirguey, C., Schwartz, C., Morel, J.L., 2006. Response of Thlaspi caerulescens to nitrogen, phosphorus and sulfur fertilisation. Int. J. Phytoremediation 8, 149-161.

Sirguey, C., Seznec, G., Mahevas, T., Echevarria, G., Gonneau, C., Sterckeman, T., 2018. Soil trace metal content does not affect the distribution of the hyperaccumulator Noccaea caerulescens in the Vosges Mountains (France). Plant Soil 430, 245-262.

Sterckeman, T., Puschenreiter, M., Van der Ent, A., Echevarria, G., Baker, A.J.M., Morel, J.-L., 2018. Phytoextraction of cadmium: feasibility in field applications and potential use of harvested biomass. Agromining: Farming for Metals. Springer Nature Switzerland, pp. 205-219.

Sterckeman, T., Perriguey, J., Caël, M., Schwartz, C., Morel, J.L., 2004. Applying a mechanistic model to cadmium uptake by Zea mays and Thlaspi caerulescens: consequences for the assessment of the soil quantity and capacity factors. Plant Soil 262, 289-302.

Tolrà, R.P., Poschenrieder, C., Barceló, J., 1996. Zinc hyperaccumulation in Thlaspi caerulescens. I. Influence on growth and mineral nutrition. J. Plant Nutr. 19 (12), 1531-1540.

Walker, D.J., Bernal, M.P., 2004. The effects of copper and lead on growth and zinc accumulation of Thlaspi caerulescens J. and C. Presl: implications for phytoremediation of contaminated soils. Water Air Soil Pollut. 151, 361-372.

Wang, A.S., Angle, J.S., Chaney, R.L., Delorme, T.A., Reeves, R.D., 2006. Soil pH effects on uptake of Cd and Zn by Thlaspi caerulescens. Plant Soil 281, 325-337.

Xie, H.L., Jiang, R.F., Zhang, F.S., McGrath, S.P., Zhao, F.J., 2009. Effect of nitrogen form on the rhizosphere dynamics and uptake of cadmium and zinc by the hyperaccumulator Thlaspi caerulescens. Plant Soil 318, 205-215.

Yanai, J., Zhao, F.J., McGrath, S.P., Kosaki, T., 2006. Effect of soil characteristics on Cd uptake by the hyperaccumulator Thlaspi caerulescens. Environ. Pollut. 139, 167-175.

Zhao, F.J., Hamon, R.E., Lombi, E., McLaughlin, M.J., McGrath, S.P., 2002. Characteristics of cadmium uptake in two contrasting ecotypes of the hyperaccumulator Thlaspi caerulescens. J. Exp. Bot. 53, 535-543.

Zhao, F.., Lombi, E., McGrath, S.P., 2003. Assessing the potential for zinc and cadmium phytoremediation with the hyperaccumulator Thlaspi caerulescens. Plant Soil 249, 37-43. 